Geological Society of America

Penrose Conference Field Trip Guide 2006

\title{
Fault Slip Transfer in the Eastern California Shear Zone- Walker Lane Belt
}

\author{
Jeffrey Lee* \\ Department of Geological Sciences, Central Washington University, Ellensburg, Washington 98926, USA \\ Daniel Stockli \\ Geology Department, University of Kansas, Lawrence, Kansas 66045, USA
}

Jeffrey Schroeder

Department of Geological Sciences, Central Washington University, Ellensburg, Washington 98926, USA, and Geology Department, University of Kansas, Lawrence, Kansas 66045, USA

Christopher Tincher

David Bradley

Geology Department, University of Kansas, Lawrence, Kansas 66045, USA

Lewis Owen

Department of Geology, University of Cincinnati, Cincinnati, Ohio 45221, USA

John Gosse

Department of Earth Sciences, Dalhousie University, Halifax, Nova Scotia, Canada B3H 3J5

Robert Finkel

Center for Accelerator Mass Spectrometry, Lawrence Livermore National Laboratory, Livermore, California 94550, USA

Jason Garwood

Department of Geological Sciences, Central Washington University, Ellensburg, Washington 98926, USA

\section{INTRODUCTION}

The Eastern California Shear Zone and Walker Lane Belt define a broad zone of active deformation that straddles the boundary between dominantly east-west extension in the Basin and Range province and dominantly NW-dextral shear directed along the Pacific-North American plate boundary to the west (Fig. 1). The interaction between extension and transcurrent shear has resulted in a complex array of NWstriking dextral faults, NW-striking and NE-striking normal faults, and ENE-striking sinistral faults that accommodate intraplate strain east of the Sierra Nevada and into western Nevada (Figs. 1 and 2).

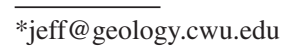

Lee, J., Stockli, D., Schroeder, J., Tincher, C., Bradley, D., Owen, L., Gosse, J., Finkel, R., and Garwood, J., 2006, Fault slip transfer in the Eastern California Shear Zone-Walker Lane Belt: Geological Society of America Penrose Conference Field Trip Guide (Kinematics and Geodynamics of Intraplate Dextral Shear in Eastern California and Western Nevada, Mammoth Lakes, California, 21-26 April 2005), 26 p., doi: 10.1130/2006.FSTITE.PFG. For permission to copy, contact editing@geosociety.org. @2006 Geological Society of America. 
Plate circuit calculations suggest that motion of the Pacific plate relative to the North American plate changed from $\mathrm{W}$ to NW at ca. 7-8 Ma (Atwater and Stock, 1998). This observation is in good agreement with regional geologic constraints, which indicate that motion of the Sierra Nevada block relative to stable North America also changed from W to NW at ca. 8-10 Ma (Wernicke and Snow, 1998; Snow and Wernicke, 2000). A recent tectonic reconstruction of southwestern North America shows that a portion of plate boundary dextral shear jumped into the continent at 10-12 Ma (McQuarrie and Wernicke, 2005). On the basis of geologic studies, the rate of dextral shear within the Eastern California Shear Zone-Walker Lane Belt north of the Garlock fault has been $\sim 15 \mathrm{~mm} / \mathrm{yr}$ since ca. 7-8 Ma (Wernicke and Snow, 1998), accounting for $\sim 30 \%$ of the relative plate motion (Atwater and Stock, 1998). Today, geodetic data indicate that dextral shear, at a rate of $\sim 10-13 \mathrm{~mm} / \mathrm{yr}$, still dominates within the Eastern California Shear Zone-Walker Lane Belt, accounting for $20 \%-25 \%$ of the total relative plate motion (Gan et al., 2000; McClusky et al., 2001; Oldow et al., 2001; Miller et al., 2001; Bennett et al., 2003).

In the northern Eastern California Shear Zone, dextral shear is accommodated to the east of the Sierra Nevada along three major, subparallel strike-slip fault zones, the Death Valley-Furnace Creek, Fish Lake Valley, and White Mountains-Owens Valley fault zones (Figs. 2 and 3). At the northern end of the Eastern California Shear Zone, NW-striking strike-slip faults abruptly swing eastward into an array of NE-striking normal and ENE-striking sinistral faults in the southern portion of the Walker Lane Belt known as the Mina deflection (Figs. 2 and 3). These curvilinear faults often form a " $z$ "-shaped extensional relay zone that transfers residual plate motion eastward from the Death Valley-Furnace Creek, Fish Lake Valley, and White Mountains-Owens Valley fault zones into the Central Nevada Seismic Belt and Walker Lane Belt (e.g., Oldow, 1992; Oldow et al., 2001; Wesnousky, 2005). Within the Eastern California Shear Zone to the south, similar extensional relay zones, such as the Deep Springs and Towne Pass faults, transfer dextral slip from one strike-slip fault system to another (e.g., Lee et al., 2001).

During the past 10-15 years, a number of geologists and geodesists have been investigating the distribution of fault slip in space and time across the Eastern California Shear Zone and Walker Lane Belt to document the kinematics of strain release and strain accumulation and thereby provide insight into the geodynamic evolution of the region.

This field trip guide will focus on the kinematics of faulting across an extensional relay zone from the northern Eastern California Shear Zone into the southern Walker Lane Belt. We will review evidence for active dextral slip along the NW-striking White Mountains fault zone, normal slip along the NE-striking Queen Valley fault, and sinistral slip along the ENE-striking Coaldale fault, and the kinematics of fault slip transfer from one fault system to another (Fig. 3).

Keywords: active tectonics, normal faults, strike-slip faults, age dating.

\section{WHITE MOUNTAINS FAULT ZONE}

\section{Regional Setting}

The White Mountains fault zone is exposed along the western flank of the White Mountains and the eastern side of the Owens, Chalfant, and Hammil valleys in east-central California (Fig. 3). It extends $\sim 115 \mathrm{~km}$ from $\sim 10 \mathrm{~km}$ south of the Waucoba Embayment northward past the town of Benton and forms a major escarpment with up to $3 \mathrm{~km}$ of topographic relief.
Deformed Precambrian to Mesozoic metasedimentary and igneous rocks and Cenozoic volcanic rocks underlie the White Mountains (e.g., Krauskopf, 1968; Crowder and Ross, 1972; McKee et al., 1982; Ernst and Hall, 1987; McKee and Conrad, 1996). Quaternary coarse- to fine-grained alluvial fan deposits interbedded with tuffaceous sand, partially welded tuff, and Bishop ash cover the base of the White Mountains and the valley floor.

The metamorphic and penetrative deformational fabrics in the White Mountains are attributed to tectonism accompanying arc magmatism in the Late Jurassic to Late Cretaceous (Stevens 


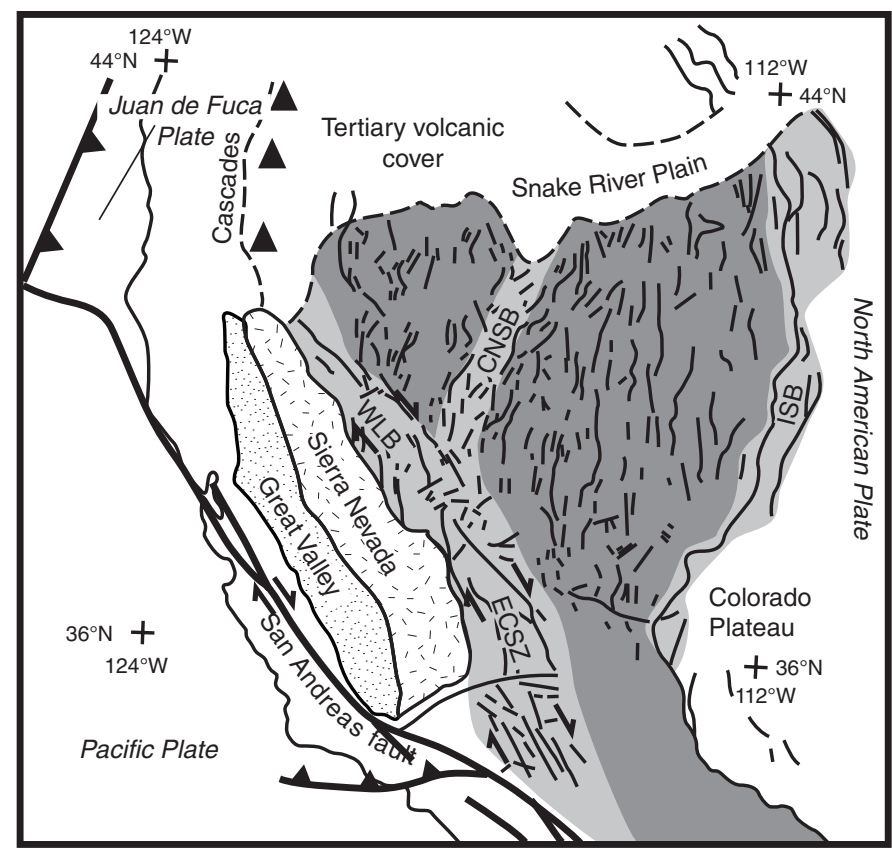

Figure 1. Simplified tectonic map of the western part of the U.S. Cordillera showing the major geotectonic provinces and modern plate boundaries. Basin and Range extensional province in dark gray; light gray: Central Nevada Seismic Belt-CNSB; eastern California shear zoneECSZ; intermountain seismic belt-ISB; Walker Lane Belt-WLB.

et al., 1997; Dunne and Walker, 2004). Unconformably overlying Miocene volcanic rocks dip up to $25^{\circ}$ to the east and record Cenozoic tilting along the west-dipping White Mountains fault zone. Investigations of the structural and thermal history (apatite fission track and (U-Th)/He thermochronologic data) of the White Mountains indicates rapid exhumation and eastward tilting in the middle Miocene, starting ca. 12 Ma (Stockli et al., 2003). Fault kinematic analysis shows that dip-slip indicators are overprinted by right-lateral slickenfibers and striations, demonstrating that the range bounding White Mountains fault zone was reactivated as a dextral strike-slip fault system (Stockli et al., 2003).

Active fault structures also indicate that right lateral slip has been superimposed on the west-dipping normal fault system (de Polo, 1989; Schroeder, 2003). The active fault zone is characterized by a network of NNE-striking, W-dipping normal faults and NNW-striking right lateral faults that cut both Mesozoic and older basement and Quaternary sedimentary rocks (Fig. 4). Welldeveloped strike-slip geomorphic features, such as linear fault scarps, offset alluvial fans, deflected drainages, closed depressions, ponded alluvium, and shutter ridges, indicate the White Mountains fault zone has been active during the Quaternary.

\section{Alluvial Fan Surfaces}

Based on alluvial fan surface morphology, such as terrace height, degree of fan dissection, presence or absence of bar and

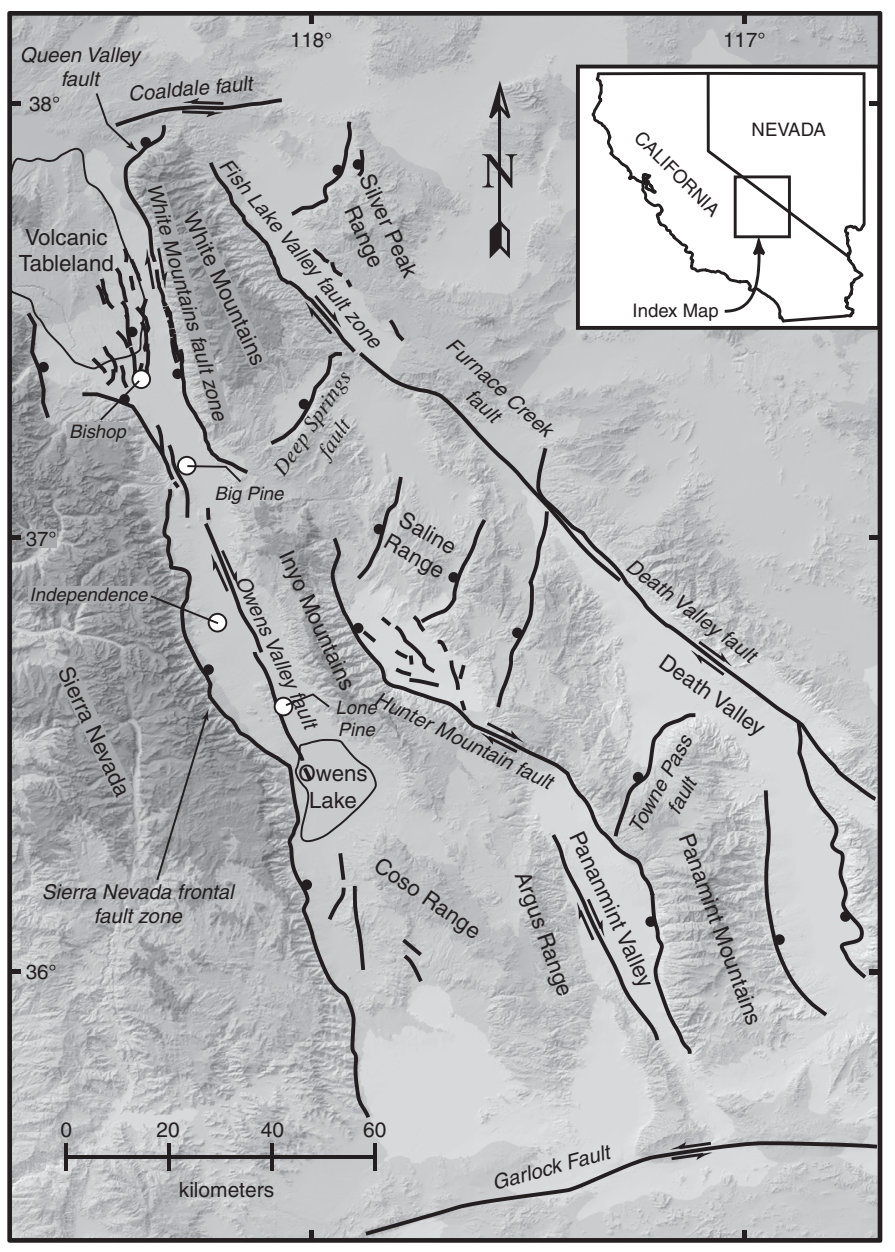

Figure 2. Shaded relief map showing major Quaternary faults in the Northern Eastern California Shear Zone-southern Walker Lane Belt. Solid circles are located on the hanging wall of normal faults; arrows indicate relative motion across strike-slip faults. Inset shows map location.

swale morphology, and degree of desert pavement development, four Quaternary alluvial fan surfaces of different ages have been mapped along the central part of the western flank of the White Mountains (Schroeder, 2003) (Fig. 4). The oldest alluvial fan surfaces, Qf1, are present throughout the field area and are highly dissected, from meters to tens of meters, into a ridge and ravine pattern (Fig. 5). Based on the degree of dissection and inset geometry, the Qf1 surfaces are subdivided into three units, from oldest to youngest: Qf1a, Qf1b, and Qf1c. All Qf1 surfaces appear light in color in aerial photographs due to the lack of rock varnish.

Observed only in the northernmost portion of the field area, the next youngest fan surface, Qf2 (Figs. 4 and 8), possesses a relatively smooth surface that is moderately dissected with a partially developed desert pavement. Qf2 surfaces are significantly darker in aerial photographs due to a well-developed rock varnish on surface clasts.

The next youngest set of surfaces, Qf3, is made up of areally extensive fans debouching from canyons within the White 


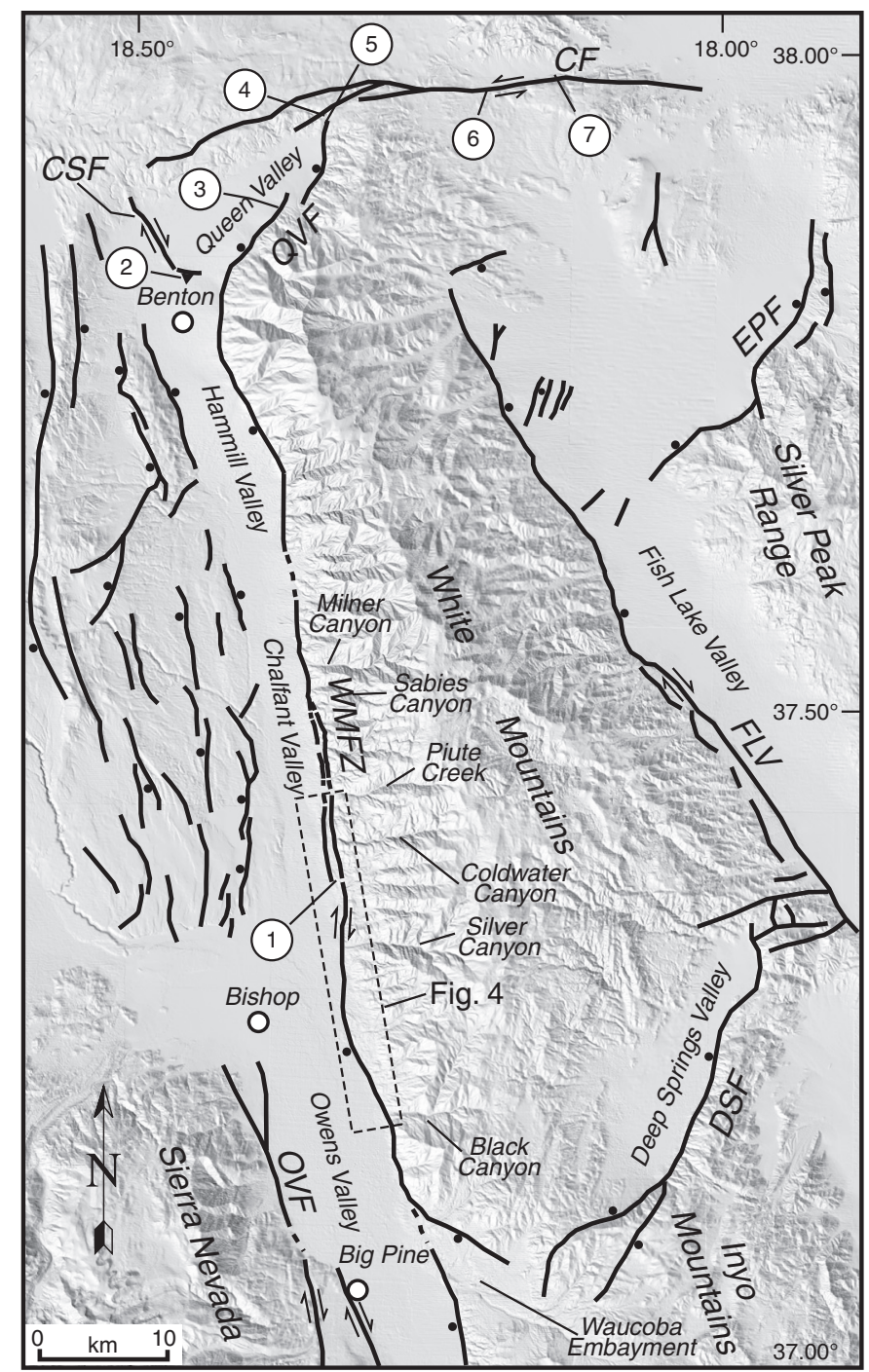

Figure 3. Shaded relief map showing major Quaternary faults in the White Mountains region and field trip stops (circled numbers). Fault abbreviations: $\mathrm{CF}$-Coaldale fault; CSF-Coyote Springs fault; DSF-Deep Springs fault; EPF_Emigrant Peak fault; FLV_Fish Lake Valley fault zone; OVF-Owens Valley fault; QVF-Queen Valley fault; WMFZ - White Mountains fault zone. Solid circles are located on the hanging wall of normal faults; arrows indicate relative motion across strike-slip faults.

Mountains (Fig. 4). Qf3 possesses well-developed bar and swale surface morphology, yielding a plumose texture. Based on the degree of bar and swale development and inset geometry, Qf3 surfaces are subdivided into two subunits, from oldest to youngest: Qf3a and Qf3b. Due to minimal rock varnish development, all Qf3 surfaces appear lighter colored than Qf2 surfaces in aerial photographs (Figs. 5, 6, 7, 8, and 9).

Bouldery bars and channels characterize Qf4, the youngest surface. Qf4 represents active or recently abandoned channels within alluvial fans. Locally, trees are present along these channels, and desert pavement and rock varnish are absent (Fig. 7).

\section{Cosmogenic Radionuclide Surface Exposure Dating Results}

To determine the age of abandonment of alluvial fan surfaces, eight samples were collected from the surfaces of quartzrich in situ granitic boulders, and 22 bulk samples were collected from three 1.0-1.5 m deep soil pits for cosmogenic radionuclide (CRN) exposure dating. Boulder samples were collected from Qf1a and Qf1b surfaces in Poleta Canyon (Fig. 5) and pit samples were collected from a Qf1a surface in Poleta Canyon and Qf1a and Qf3a surfaces north of Gunter Creek. Samples were processed and analyzed, and the data were reduced as described in Owen et al. (2001, 2002).

Boulder samples OV1, OV3, and OV5, collected from Qf1 surfaces, yield ${ }^{10} \mathrm{Be} C R N$ model ages ranging from $232.3 \pm 5.3 \mathrm{ka}$ to $200.1 \pm 7.3 \mathrm{ka}$, while samples OV2, OV4, OV6, OV7, and OV8, also collected from Qf1 surfaces, yield ages ranging from $140.4 \pm 3.5 \mathrm{ka}$ to $25.0 \pm 0.9 \mathrm{ka}$. There is no correlation between CRN model age and whether the sample was collected from a Qf1a or Qf1b surface. The boulders from which samples OV2, OV4, OV6, OV7, and OV8 were collected were more weathered and exfoliated than the boulders sampled for OV1, OV3, and OV5. We therefore interpret the younger ages as a consequence of severe weathering and/or recent exhumation of overlying sediment that may have shielded the boulder. Samples OV1, OV3, and OV5 yield a mean ${ }^{10} \mathrm{Be} C R N$ model age of $217.5 \pm 16.3 \mathrm{ka}$, which we interpret as a minimum age for the abandonment of the Qf1 surface. Assuming a boulder erosion rate of $0.2 \mathrm{~cm} / \mathrm{k} . \mathrm{y}$., calculated for granite boulders surrounding the Fish Springs cinder cone (Zehfuss et al., 2001), the Qf1 surface abandonment age increases to $338 \pm 34 \mathrm{ka}$.

Bulk sediment samples from the three pits do not yield consistent ${ }^{10} \mathrm{Be} \mathrm{CRN}$ model age patterns with depth, most likely because of inheritance and possible erosion of the surface. Additional samples have been collected recently to try to solve this issue.

\section{Right Lateral Offsets}

Well-developed strike-slip geomorphic features, such as linear fault scarps, east- and west-facing fault scarps, offset alluvial fans, deflected drainages, closed depressions, ponded alluvium, and shutter ridges from Black Canyon to Piute Creek (Figs. 4, $6,7,8$, and 9), indicate active right-lateral strike-slip along the White Mountains fault zone. Locations of right-lateral offset of piercing points along the White Mountains fault zone are shown in Figure 4. Maximum offset of drainages developed within Qf1 surfaces; the oldest fan surface is $\sim 492 \mathrm{~m}$, while the minimum offset of $\sim 5 \mathrm{~m}$ and $\sim 9 \mathrm{~m}$ is observed within Qf3a fan surfaces. Minimum offset of drainages developed within the intermediate age surface, Qf2, is $\sim 24-35 \mathrm{~m}$.

A set of three right-laterally offset stream channels and ridges are developed within a Qf1a fan surface at Poleta Canyon (Figs. 4 and 6). A detailed topographic map of the middle stream channel thalweg and ridge crest, which illustrates the most obvious measurable offset, shows the drainage thalweg and ridge crest offset 


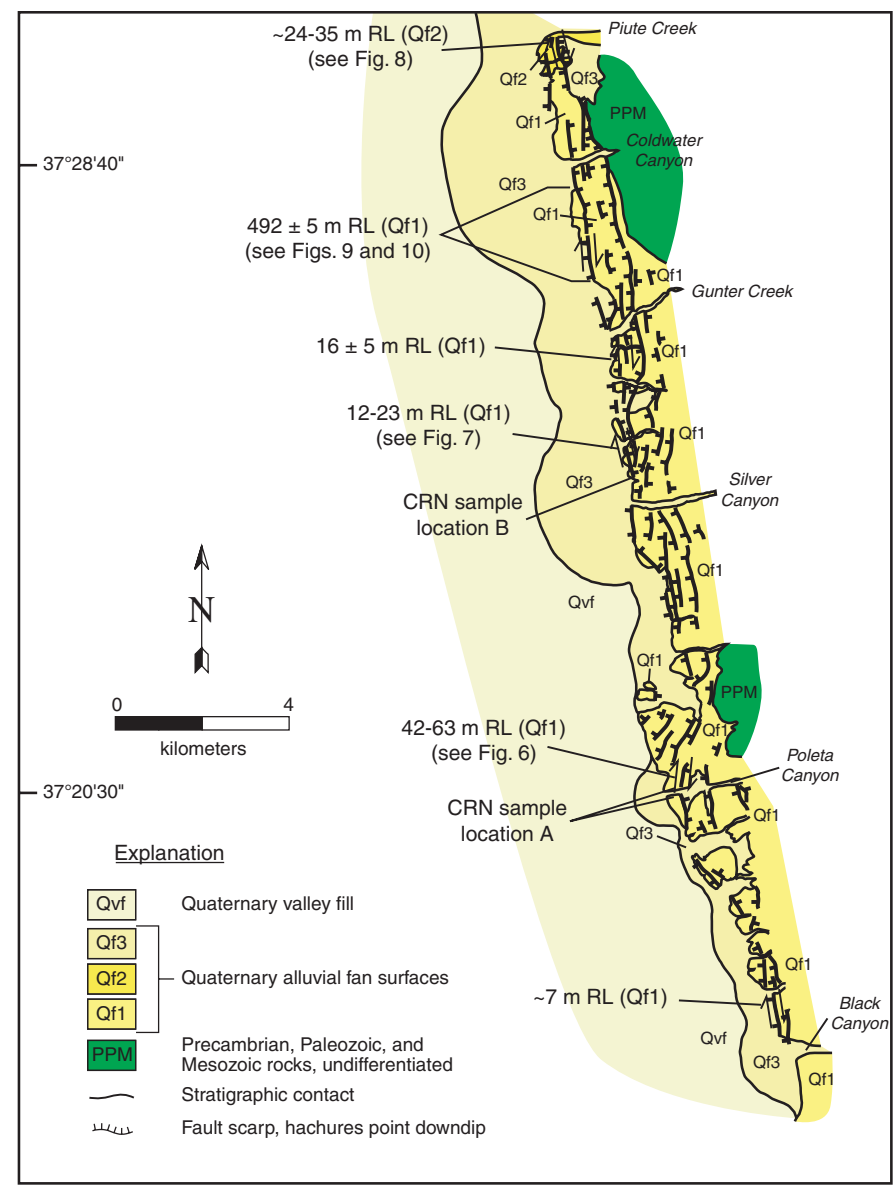

Figure 4. Simplified geologic map along the central White Mountains fault zone showing major fault scarps cutting Quaternary alluvial fan surfaces, locations of measured dextral offset of specific alluvial fan surfaces, cosmogenic radionuclide (CRN) sample locations, and major canyons in the White Mountains. RL-right lateral. See Figure 3 for map location. Modified from Schroeder (2003).

$42 \pm 7 \mathrm{~m}$ and $63 \pm 13 \mathrm{~m}$, respectively (Fig. 6). There is no apparent vertical separation of these landforms. To the north, the fault is covered by a Qf3a surface and therefore cannot be traced farther. A large shutter ridge on the south side of Poleta Canyon defines the southern continuation of this fault. The absence of faulting within the Qf3b fan surface indicates that right-lateral motion at this location occurred prior to the development of this surface.

Exposed $\sim 1 \mathrm{~km}$ north of Silver Canyon is a shutter ridge and channel wall developed within a Qf1a fan surface that exhibit dextral offset of $12 \pm 3 \mathrm{~m}$ and $23 \pm 7 \mathrm{~m}$, respectively (Figs. 4 and 7). Since the ridge crest projects into the active channel, erosion has most likely removed part of the shutter ridge. Therefore, $12 \mathrm{~m}$ underestimates the magnitude of dextral offset. The apparent vertical separation, dominantly west side up, suggests that the topographic relief is the result of laterally displaced landforms. Although the trace of this fault clearly continues another kilometer north, where it becomes concealed by a Qf3a fan surface, this segment lacks evidence for right-lateral motion. The southern

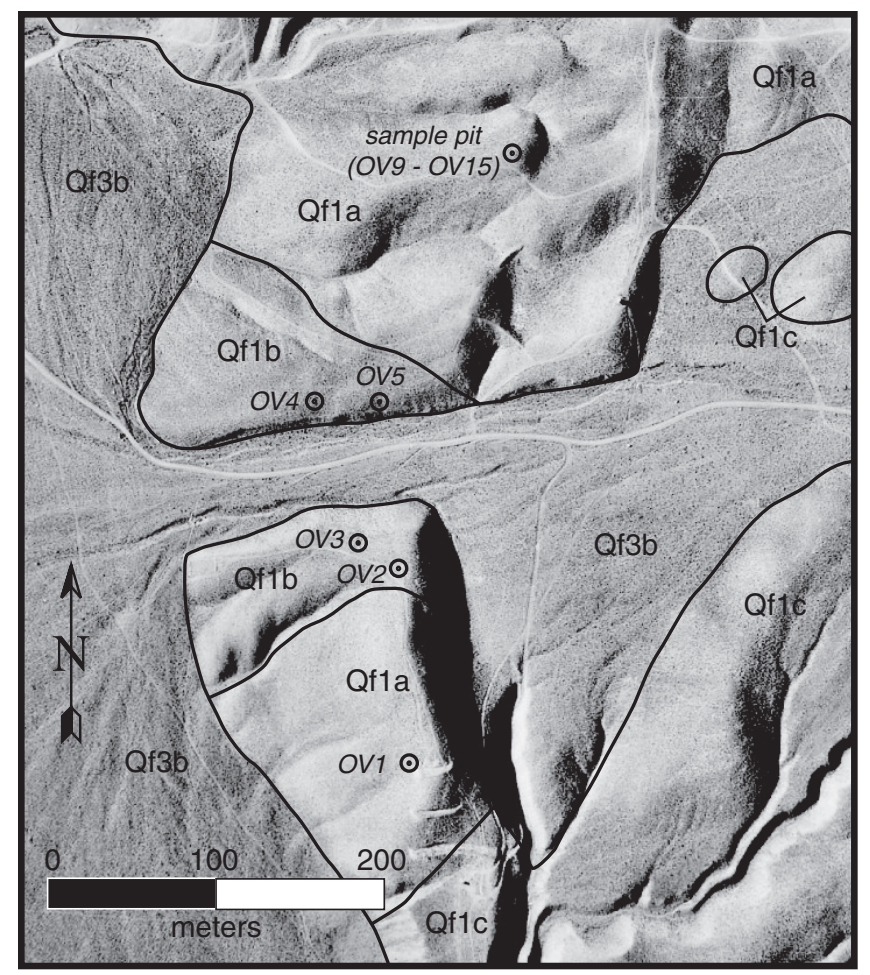

Figure 5. Aerial photograph showing the strongly dissected ridge and ravine morphology of Qf1a, Qf1b, and Qf1c surfaces, the weakly dissected, bar and swale surface morphology of Q3b surfaces, and cosmogenic radionuclide boulder (OV1-5) and pit (OV9-15) sample locations. Faults are not highlighted.

continuation of this fault trace is not exposed because it is buried by a Qf3b fan surface.

The region that exposes the maximum amount of dextral offset across the White Mountains fault zone is located between Gunter Creek and Coldwater Canyon (Figs. 4, 9, and 10). In this area, stream channels incised into Qf1a and Qf1b fan surfaces are dextrally offset by the main trace of the fault and three subparallel fault splays, defining a fault zone $\sim 425 \mathrm{~m}$ wide. Restoration of stream channel pairs $\mathrm{C} 1$ and $\mathrm{C} 2 \mathrm{a}, \mathrm{C} 2 \mathrm{~b}$, and $\mathrm{C} 2 \mathrm{c}$ across the main fault trace yields right-lateral offsets of $358 \pm 8 \mathrm{~m}$ and an average of $492 \pm 5 \mathrm{~m}$, respectively (Figs. 9 and 10). Offset of channel C1 is less than channels $\mathrm{C} 2 \mathrm{a}, \mathrm{C} 2 \mathrm{~b}$, and $\mathrm{C} 2 \mathrm{c}$, possibly because it is younger and, therefore, has not been dextrally offset to the same degree. Apparent vertical offset (west-side up) of channel pairs $\mathrm{C} 1$ and $\mathrm{C} 2$ is $32 \pm 2 \mathrm{~m}$ and $26 \pm 1 \mathrm{~m}$, respectively. Terraces along both sets of channels on the east side of the fault, but not on the west side, suggest that downcutting continued in these channels after offset, thereby explaining, at least in part, the apparent vertical separation. Some of the channels crossed by fault splays A, B, and C exhibit right-lateral deflection, but no offset. The southern continuation of the main fault is buried by the active Gunter Creek alluvial fan surface, Qf3b; the three fault splays are buried by a Qf3a surface. The northern extension of the main fault continues for $\sim 1 \mathrm{~km}$ before it splays into several additional subparallel fault splays. While dextral 

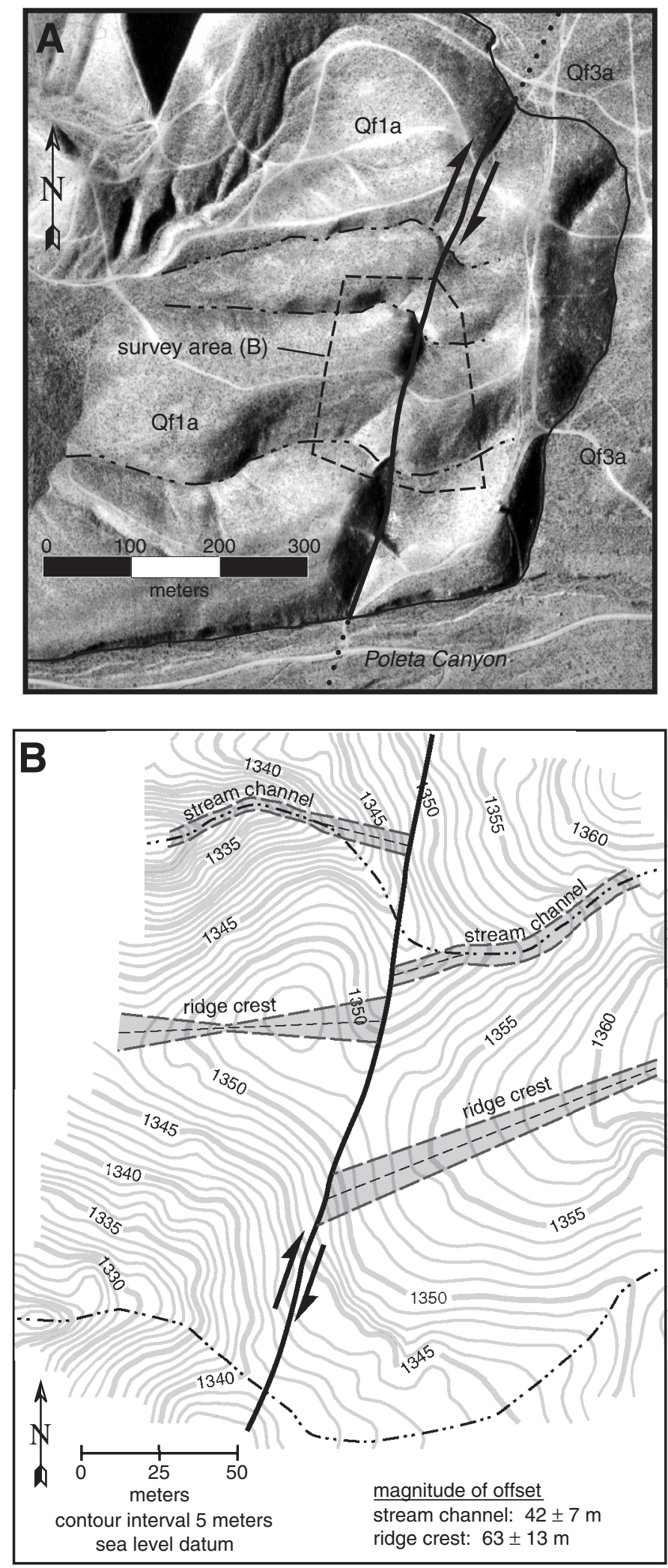

Figure 6. (A) Aerial photograph with geologic interpretation showing three dextrally offset channels (dash-dot lines) and ridge crests near Poleta Canyon. Only the primary fault trace is highlighted. (B) Differential global positioning system-generated detailed topographic map of the boxed area in (A) illustrating $63 \pm 13 \mathrm{~m}$ dextral offset of the ridge crest and $42 \pm 7 \mathrm{~m}$ dextral offset of a channel. Thin, dashed line highlights the offset geomorphic features; shaded areas represent error envelopes. Modified from Schroeder (2003).
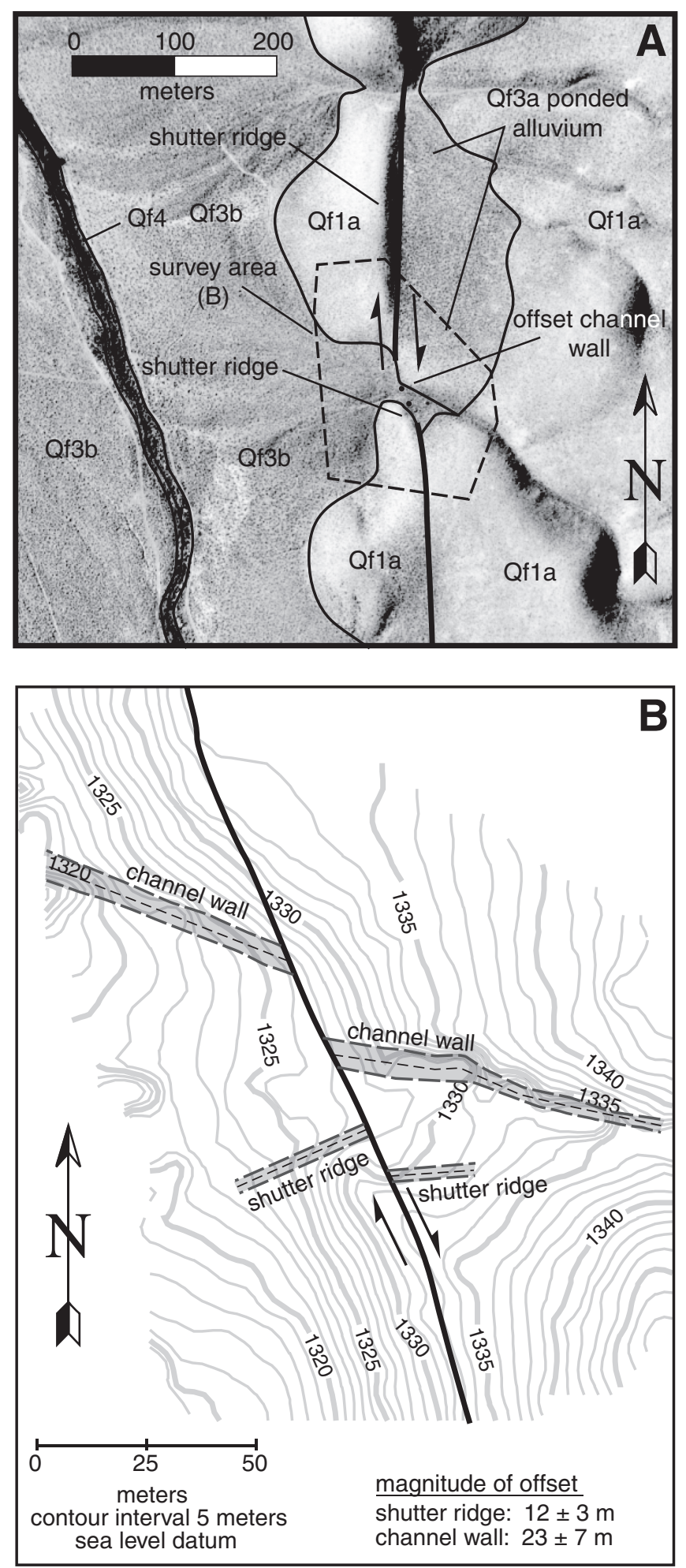

Figure 7. (A) Aerial photograph showing a shutter ridge and offset channel wall $\sim 1 \mathrm{~km}$ north of Silver Canyon. Only the primary fault trace is highlighted. (B) Differential global positioning system-generated detailed topographic map of the boxed area in (A) illustrating a shutter ridge dextrally offset $12 \pm 3 \mathrm{~m}$ and a channel wall dextrally offset $23 \pm 7 \mathrm{~m}$. Thin, dashed line highlights the offset geomorphic features; shaded areas represent the error envelopes. Modified from Schroeder (2003). 


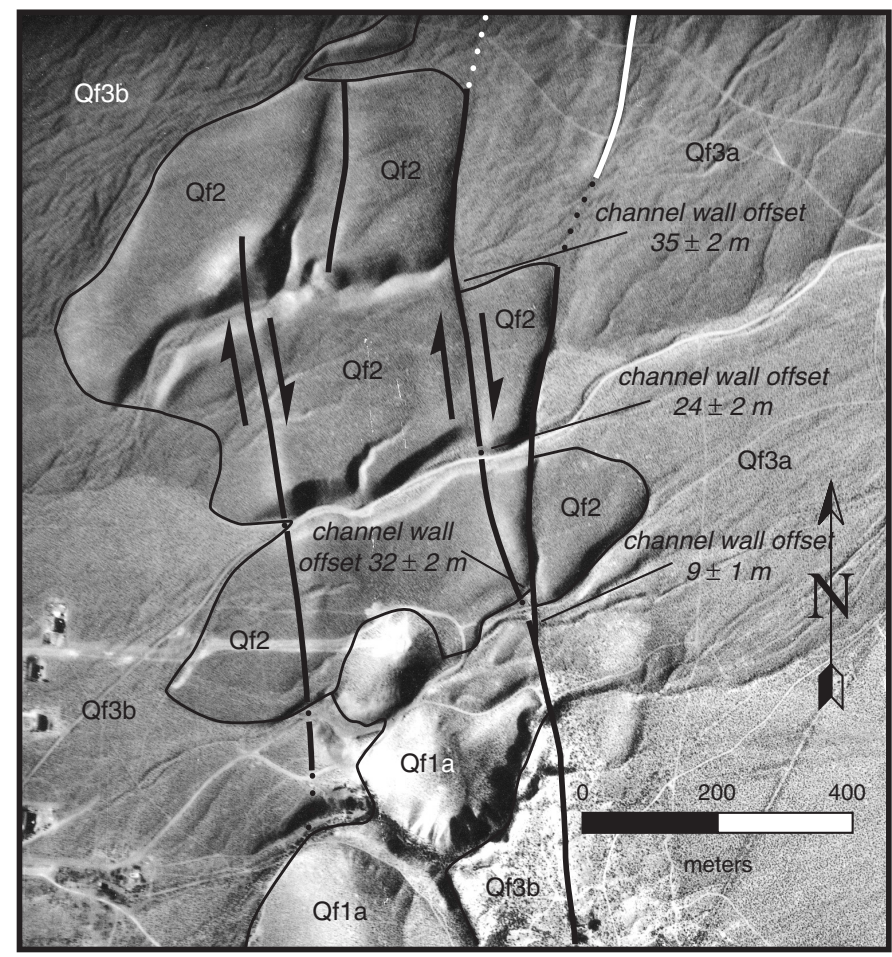

Figure 8. Aerial photograph and geologic interpretation of the offset channel walls at Piute Creek. Differential global positioning system surveying of offset channel walls developed in Qf2 yields $24 \pm 2 \mathrm{~m}$ to $35 \pm 2 \mathrm{~m}$ of dextral offset and in Qf3a yields $9 \pm 1 \mathrm{~m}$ of dextral offset.

offset is probably continuous along this fault, there are no geologic features present to determine the amount of offset. The three fault splays also appear to continue $\sim 1 \mathrm{~km}$ northward, although they are intermittently concealed by a Qf3a fan surface.

Exposed at Piute Creek fan are a series of channel walls, developed into a Qf2 surface, that show dextral offset of $24 \pm 2 \mathrm{~m}$ to $35 \pm 2 \mathrm{~m}$ (Figs. 4 and 8 ). Erosion has most likely removed part of the channel wall that shows $\sim 24$ m of dextral offset; therefore, this measurement underestimates the total offset along this fault strand. These measured offsets are minima because several fault splays cut the Qf2 surface, yet not all splays preserve evidence for dextral slip. Only the $\sim 24$ m dextrally offset channel wall shows significant vertical separation (west-side up), most likely because of down-cutting on the east-side of the fault. The faults continue south to Cold Water Canyon, at which point they become intermittently buried by Qf3 surfaces and are less discernable. Dextral offset is probably continuous along these faults, but there are no features from which to determine measurable offset. The faults continue northward as a series of NE-striking NW-dipping en echelon normal faults, which form a 1-km-wide right step in the White Mountains fault zone.

The smallest offsets documented were a deflected drainage developed within a Qf3a fan surface at the Piute Creek fan (Fig. 8) and at Sabies Canyon. Channel walls in a small drainage on the
Piute Creek fan are dextrally offset $9 \pm 1 \mathrm{~m}$ (Fig. 8); there is no apparent vertical offset. To the north, this fault scarp continues along a Qf2 surface, but after $\sim 400 \mathrm{~m}$, it is buried by a younger Qf3a surface. To the south, the fault scarp is exposed within a Qf3a surface, but no discernable lateral offset is observed. Sabies Canyon is located beyond the northernmost portion of the mapping area, but was included in field reconnaissance. Tape measurement yields $4 \pm 1 \mathrm{~m}$ and $6 \pm 1 \mathrm{~m}$ of dextral offset based on the channel thalweg and channel wall, respectively, comparable to de Polo's (1989) estimate. The fault scarp is exposed along strike for $\sim 50 \mathrm{~m}$ on either side of the channel.

\section{Slip Rates}

In Poleta Canyon, a Qf1a ridge has been dextrally offset $\sim 63 \mathrm{~m}$ across one fault strand, indicating a slip rate of $0.3 \mathrm{~mm} / \mathrm{yr}$ for the ca. $218 \mathrm{ka}$ surface. For this fault strand, this slip rate is a maximum because the age estimate for the surface is a minimum. The calculated slip rate decreases to $0.2 \mathrm{~mm} / \mathrm{yr}$ if we incorporate $0.2 \mathrm{~cm} / \mathrm{k} . \mathrm{y}$. erosion in our estimate of the Qf1 surface age at ca. $338 \mathrm{ka}$. The $0.3 \mathrm{~mm} / \mathrm{yr}$ slip rate is likely a minimum for the fault zone because this fault strand is one of several subparallel fault strands in the Poleta Canyon area, yet measurable dextral offset across the other strands cannot be determined.

The largest dextral offset, $492 \pm 5 \mathrm{~m}$, is observed within a set of channels developed within Qf1a and Qf1b surfaces exposed between Gunter Creek and Coldwater Canyon (Figs. 9 and 10). These surfaces exhibit the same degree of dissection and ridge and ravine morphology, and appear lighter in aerial photography like the $217.5 \pm 16.3 \mathrm{ka}$ Qf1a and Qf1b surfaces in Poleta Canyon $\sim 13 \mathrm{~km}$ to the south. Therefore, we tentatively conclude that the Qf1a and Qf1b surfaces exposed between Gunter Creek and Coldwater Canyon are the same age. The CRN samples from the pits were collected, in part, to test this conclusion. If our surface morphology correlations are correct, then these offset channels yield a late Pleistocene dextral slip rate of $2.3 \pm 0.2 \mathrm{~mm} / \mathrm{yr}$. Using the erosion age of $338 \pm 34 \mathrm{ka}$ for the Qf1 surfaces yields a maximum late Pleistocene dextral slip rate of $\leq 1.5 \pm 0.1 \mathrm{~mm} / \mathrm{yr}$.

\section{QUEEN VALLEY FAULT}

\section{Geological Setting}

At the northern end of the White Mountains is Queen Valley, a 16-km-long, NE-trending basin (Figs. 3, 11, and 12). Mesozoic granitic and metasedimentary rocks and Tertiary basalt lava and rhyolite tuff underlie the surrounding ranges, and alluvial fan deposits underlie the Queen Valley basin. Queen Valley forms the northern termination of the White Mountains-Owens Valley dextral fault system. An array of dextral, sinistral, normal, and thrust faults, exposed within and along the flanks of the Queen Valley basin, transfer fault slip from the White Mountains-Owens Valley dextral fault system to the Coaldale fault zone around the Mina Deflection into the south-central Walker Lane Belt. 

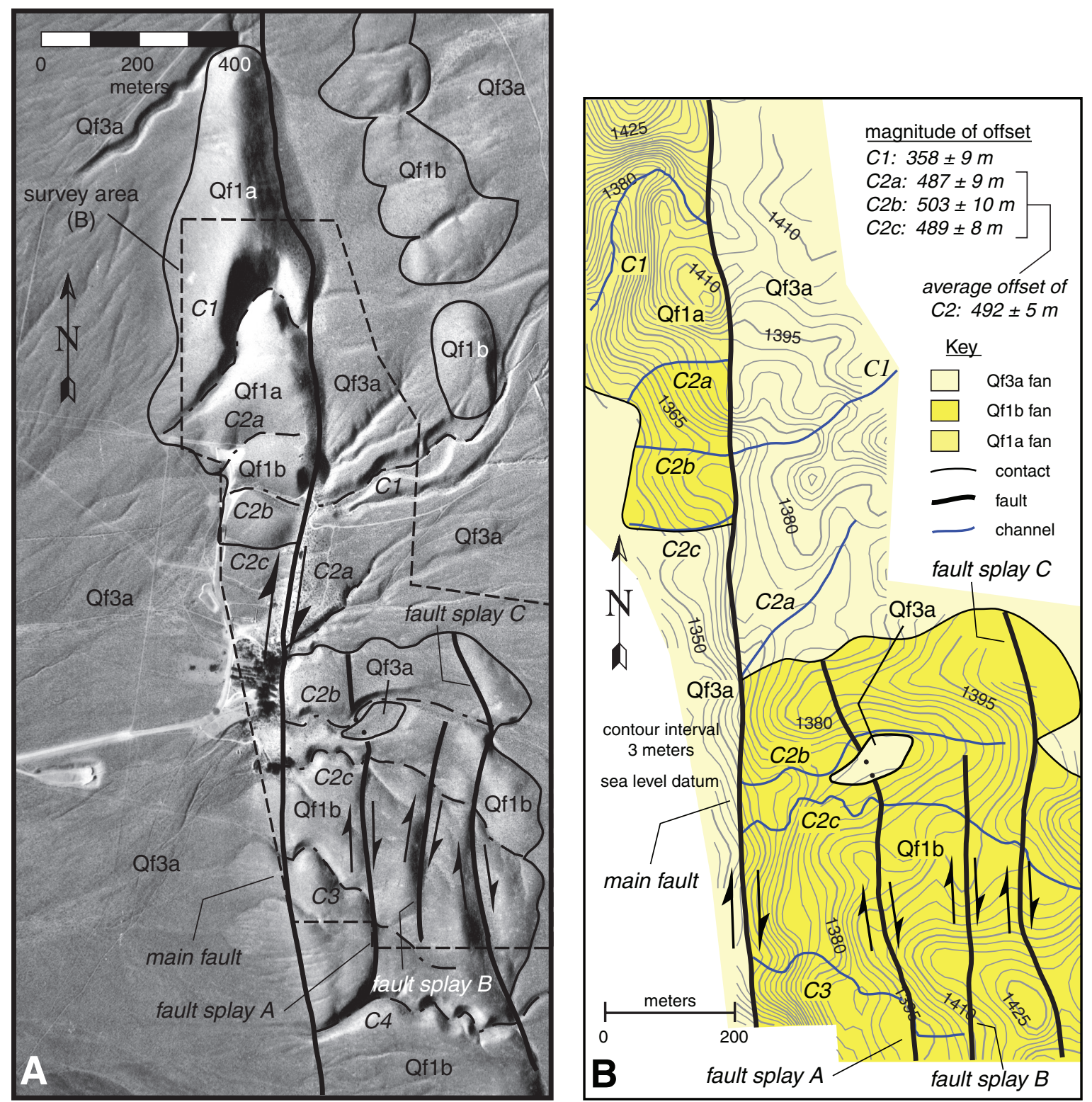

Figure 9. (A) Aerial photograph of the area that exposes the maximum right-lateral offset. Channels $\mathrm{C} 1$, and $\mathrm{C} 2 \mathrm{a}, \mathrm{C} 2 \mathrm{~b}$, and $\mathrm{C} 2 \mathrm{c}$, incised into Qf1a and Qf1b surfaces, are dextrally offset by the main fault. (B) Differential global positioning system-generated detailed topographic map of the area highlighted in (A). Modified from Schroeder (2003).

In the Queen Valley area, the orientation of the White Mountains fault zone changes abruptly from $\sim \mathrm{N}-\mathrm{S}$ to NE-SW. Here, this fault segment is informally termed the Queen Valley fault. Fault kinematic data from the NE-striking Queen Valley fault and associated smaller faults indicates that fault slip is dominated by nearly pure down-to-the-NW dip-slip motion; the extension direction is $\sim 335^{\circ}$. Near Montgomery Pass, the Queen Valley fault merges with the Coaldale fault, an E-W striking, left-lateral strike-slip fault.

The (U-Th)/He thermochronological data from the footwall of the Queen Valley fault yield ages of ca. 3-5 Ma (Fig. 13). Apatite samples yield apparent (U-Th)/He ages that decrease with decreasing elevation and exhibit an inflection point at $\sim 2200 \mathrm{~m}$, suggesting the existence of an exhumed Pliocene partial retention zone (Stockli et al., 2000). The concordant and invariant ages below $2200 \mathrm{~m}$ directly date the onset of renewed exhumation and the formation of the Queen Valley pull-apart structure at $3.0 \pm 0.5 \mathrm{Ma}$ (Fig. 13). Additional detailed work is currently under way to provide a more precise estimate for the timing and magnitude of Pliocene normal faulting and the reconstruction of geothermal gradients. Based on offset Miocene-Pliocene volcanic units and on the thickness of the Queen Valley basin fill (detailed gravity work in progress), the total normal displacement along the Queen Valley fault is estimated to be between $\sim 1.5$ and 


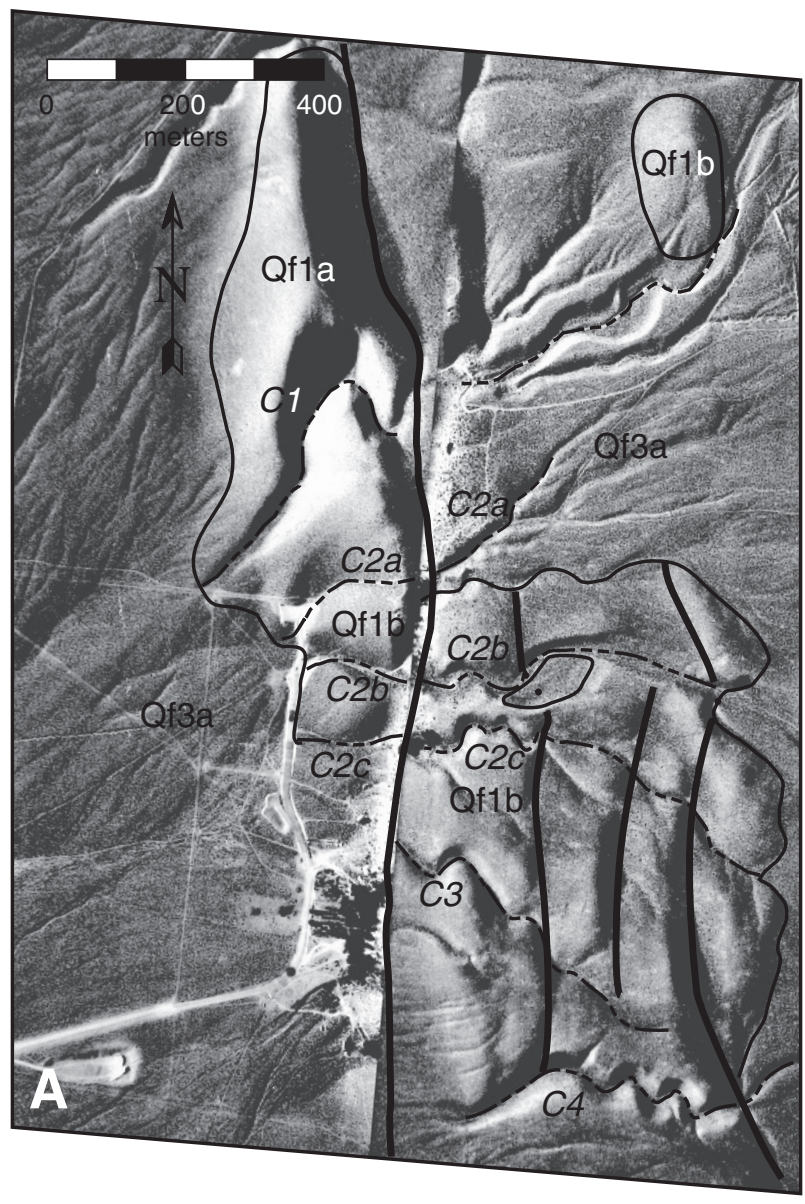

Figure 10. Restoration of $\sim 492 \mathrm{~m}$ of dextral offset of channels $\mathrm{C} 2 \mathrm{a}, \mathrm{C} 2 \mathrm{~b}$, and $\mathrm{C} 2 \mathrm{c}$ across the main trace of the White Mountains fault zone. (A) Restoration of offset of the aerial photograph shown in Figure 9. (B) Restoration of the geologic map shown in Figure 9. Note that restoration of channels $\mathrm{C} 2$ results in alignment of the northern edge of the Qf1b surface.

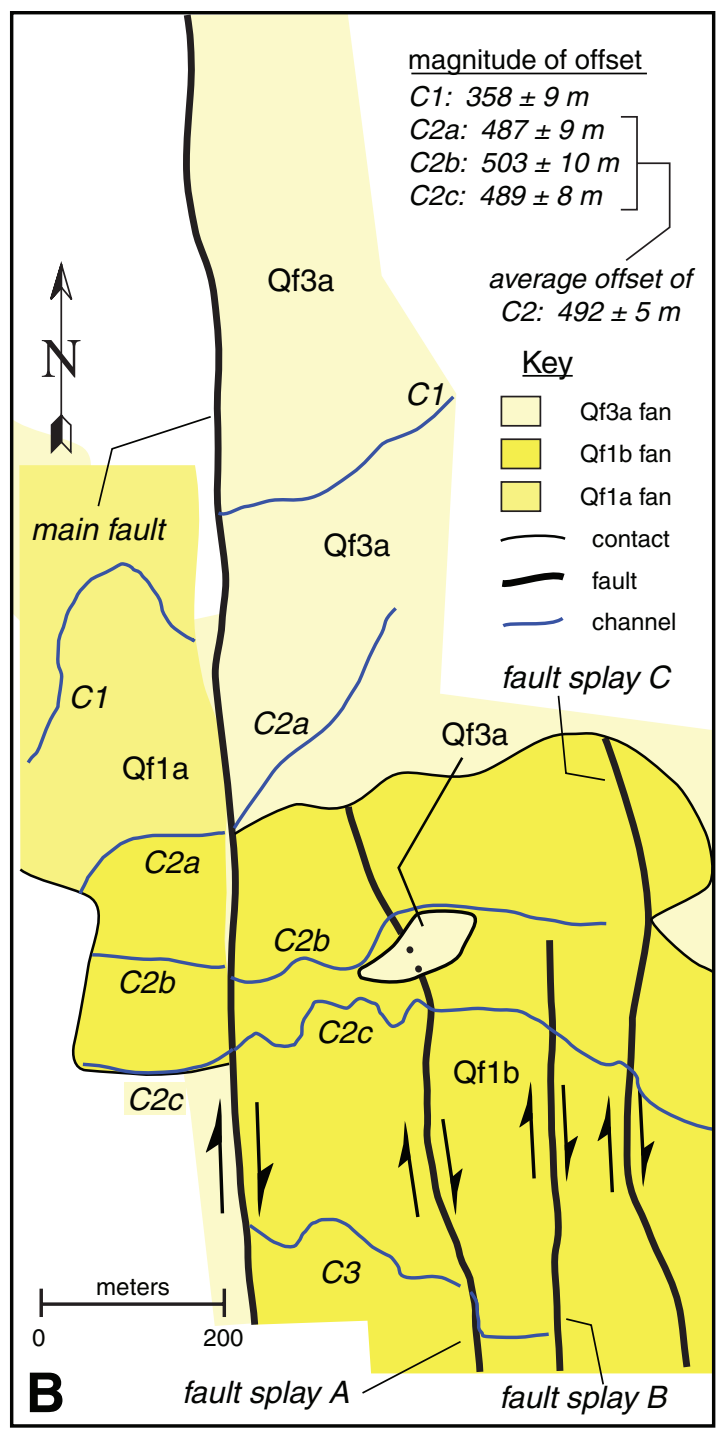

$\sim 2.5 \mathrm{~km}$. To the south of Queen Valley along the western range front of the White Mountains, no samples yield (U-Th)/He ages younger than ca. $12 \mathrm{Ma}$, suggesting that Pliocene normal displacement decreases southward along the range front away from the Queen Valley pull-apart structure.

Because the Queen Valley pull-apart structure forms the northern termination of the dextral White Mountains-Owens Valley fault system, the opening of the basin at ca. 3 Ma reflects the onset of right-lateral strike-slip faulting.

\section{Alluvial Fan Surfaces}

Queen Valley basin is underlain by four major Pleistocene to Holocene alluvial fan surfaces. These surfaces have been subdivided based on color and fan surface morphology, such as terrace height, presence or absence of bar and swale morphology, degree of fan dissection, and inset geometry (Figs. 11 and 12). The oldest surfaces, Qf1, are preserved primarily in the southwestern part of the area as highly eroded, isolated ridge and ravine remnants deposited on Tertiary basalt lava. Qf2 surfaces appear light colored and relatively smooth in aerial photography. These surfaces are often dissected by weakly developed channels spaced by a meter or so. Qf3 surfaces are distinguished in aerial photography by a light brown color and a moderately dissected appearance. These surfaces possess bar and swale morphology and bouldery debris flows adjacent (within $\sim 2.5 \mathrm{~km}$ ) to the range front. Based primarily on inset geometry, the Qf3 surfaces are subdivided into three subunits, from oldest to youngest: Qf3a, Qf3b, and Qf3c (Figs. 11 and 12). The youngest surfaces, Qf4, are generally light-colored in aerial photography and define active or recently abandoned stream channels cut into older surfaces. Active channels are commonly relatively densely vegetated, whereas abandoned ones are not. Channel deposits include unvarnished granitic and metamorphic boulders and cobbles, fresh boulder levee bars, and sand. 


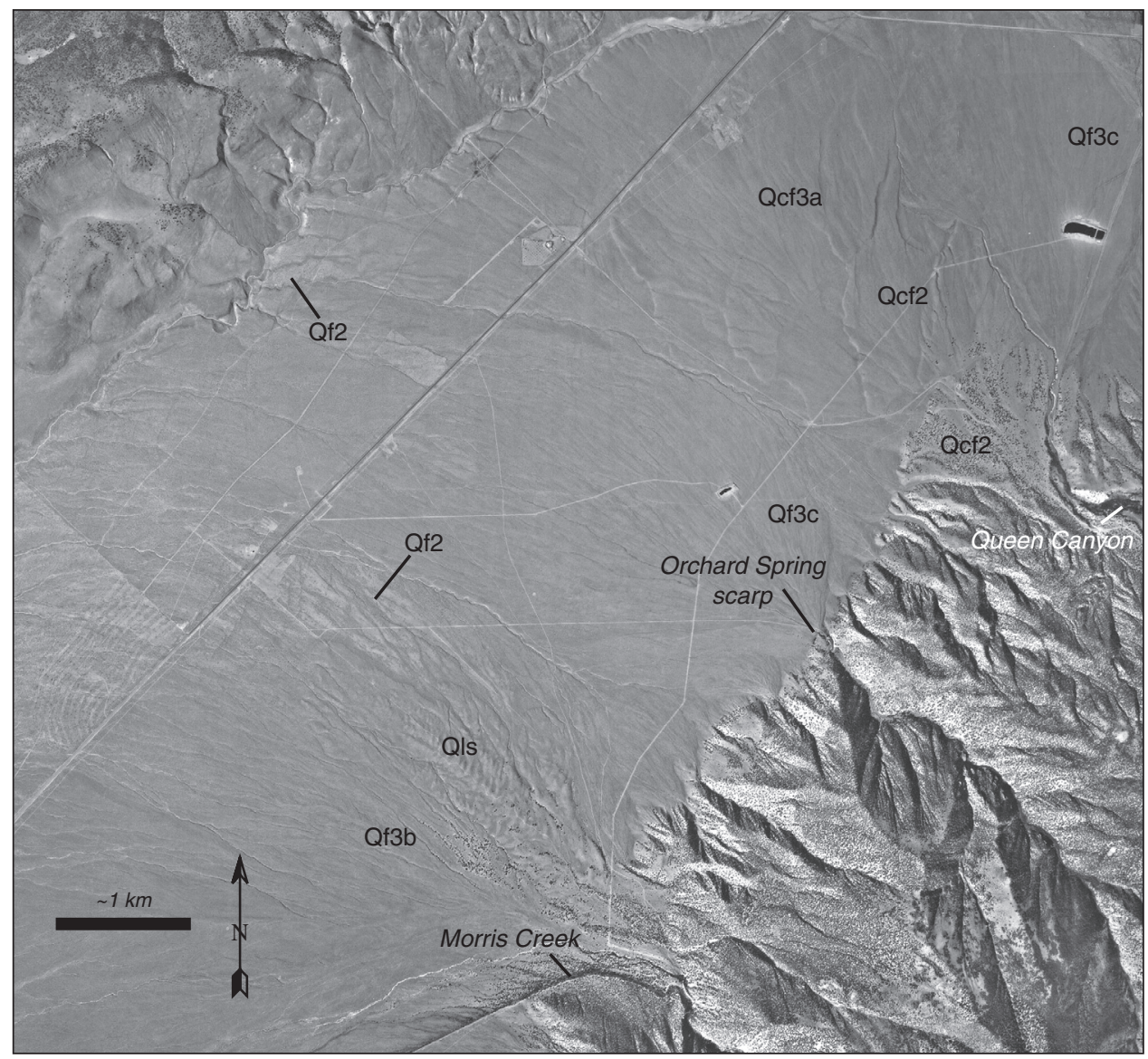

Figure 11. Aerial photograph of the Queen Valley area showing light color and weakly dissected, relatively smooth surface morphology of Qf2 surfaces, hummocky topography of Q1s deposits, weakly dissected bar and swale and plumose morphology of Qf3 surfaces, and the Orchard Spring fault scarp. Other faults are not highlighted.

Alluvial fan deposits and surfaces debouching from Queen Canyon (Qcf deposits) have been mapped as a separate alluvial fan sequence, although surface morphology and deposits are similar to the Qf surfaces described above (Figs. 11 and 12).

\section{Cosmogenic Radionuclide Surface Exposure Dating Results}

Fourteen quartz-rich granite samples were collected from the top of in situ boulders for ${ }^{10} \mathrm{Be}$ CRN surface exposure age determination of five of the alluvial fan surfaces (Figs. 12 and 14). At the mouth of Queen Canyon, boulder samples collected from Qcf1 and Qcf2 surfaces yield calculated model ${ }^{10} \mathrm{Be}$ ages of ca. $96 \mathrm{ka}$ (one sample) and $52.2 \pm 1.6 \mathrm{ka}$ (two samples), respectively (Fig. 12). One boulder sample from a debris flow on the Qcf2 surface yields a CRN model age of ca. $70 \mathrm{ka}, \sim 18 \mathrm{k}$.y. older than the other two samples. Field relations suggest that the ca. $70 \mathrm{ka}$ boulder is an exposed remnant of an older debris flow that was buried by the ca. 52 ka surface. Boulder samples collected from Qf2 and Qf3b surfaces emanating from Morris Creek yield calculated model ${ }^{10} \mathrm{Be}$ ages of $75.0 \pm 3.0 \mathrm{ka}$ (five samples) (Fig. 12) and an age range of $68.7-1.6 \mathrm{ka}$ (three samples), respectively. Field relations of boulders collected from the Qf3b surface suggest that the $68.7 \mathrm{ka}$ boulder is from a remnant debris flow and the $1.6 \mathrm{ka}$ boulder is from the youngest debris flow. Boulder samples collected from a Qf3c surface in the hanging wall of the Orchard Spring normal fault scarp yield a calculated model ${ }^{10} \mathrm{Be}$ age of $13.5 \pm 0.4 \mathrm{ka}$ (two samples) (Fig. 12).

We interpret these model ages as a minimum for surface abandonment. Erosion of the boulders likely occurred, although the average erosion rate is unknown. Nevertheless, if we assume a boulder erosion rate of $0.2 \mathrm{~cm} / \mathrm{k} . \mathrm{y}$., calculated for granite boulders surrounding Fish Springs cinder cone along the east flank of the Sierra Nevada (Zehfuss et al., 2001), then Qcf2, Qf2, and Qf3c surface abandonment ages increase to $86.7 \pm 4.0 \mathrm{ka}, 57.5$ $\pm 2.0 \mathrm{ka}$, and $13.8 \pm 0.4 \mathrm{ka}$, respectively.

\section{Active Faults and Slip Rates}

Four active fault types and fault orientations cut these alluvial fan surfaces, late Cenozoic basalt lavas, and bedrock: (1) A series of NE-striking, NW- and SE-dipping normal fault scarps cut across the SE-side of the valley and offset Qf1, Qf2, and Qf3 surfaces; (2) A set of NE-striking sinistral faults cut Qf2 surfaces on the N-side of the valley; (3) A NW-striking dextral fault cuts and offsets Tertiary basalt and Qf1, Qf2, and Qf3 surfaces along the SW-side of the valley; and this fault merges into (4) an 


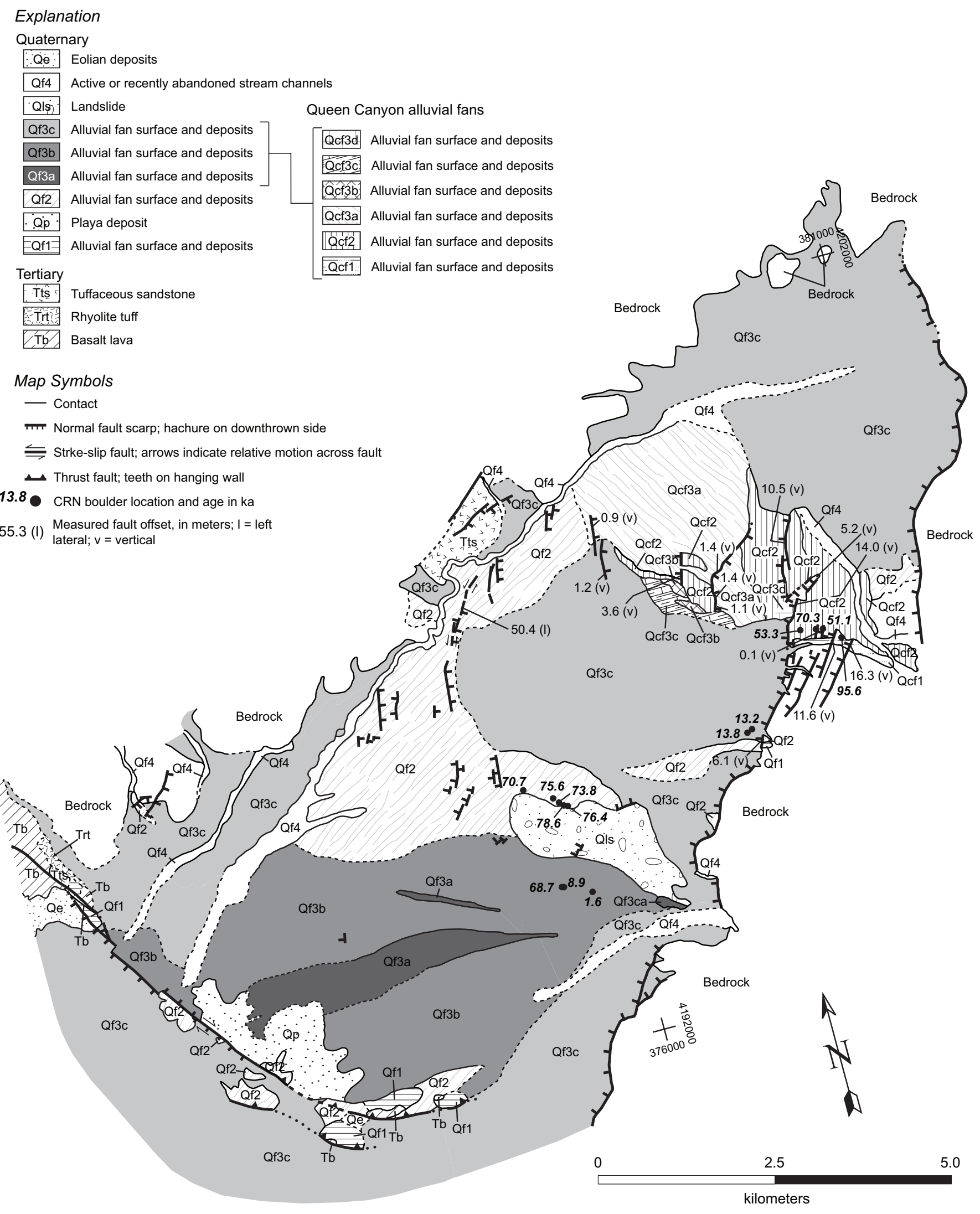

Figure 12. Simplified geologic map of the Queen Valley area showing major fault scarps cutting Tertiary basalt lavas and Quaternary alluvial fan surfaces, locations of measured vertical and sinistral offset of specific alluvial fan surfaces, and cosmogenic radionuclide (CRN) sample locations. 

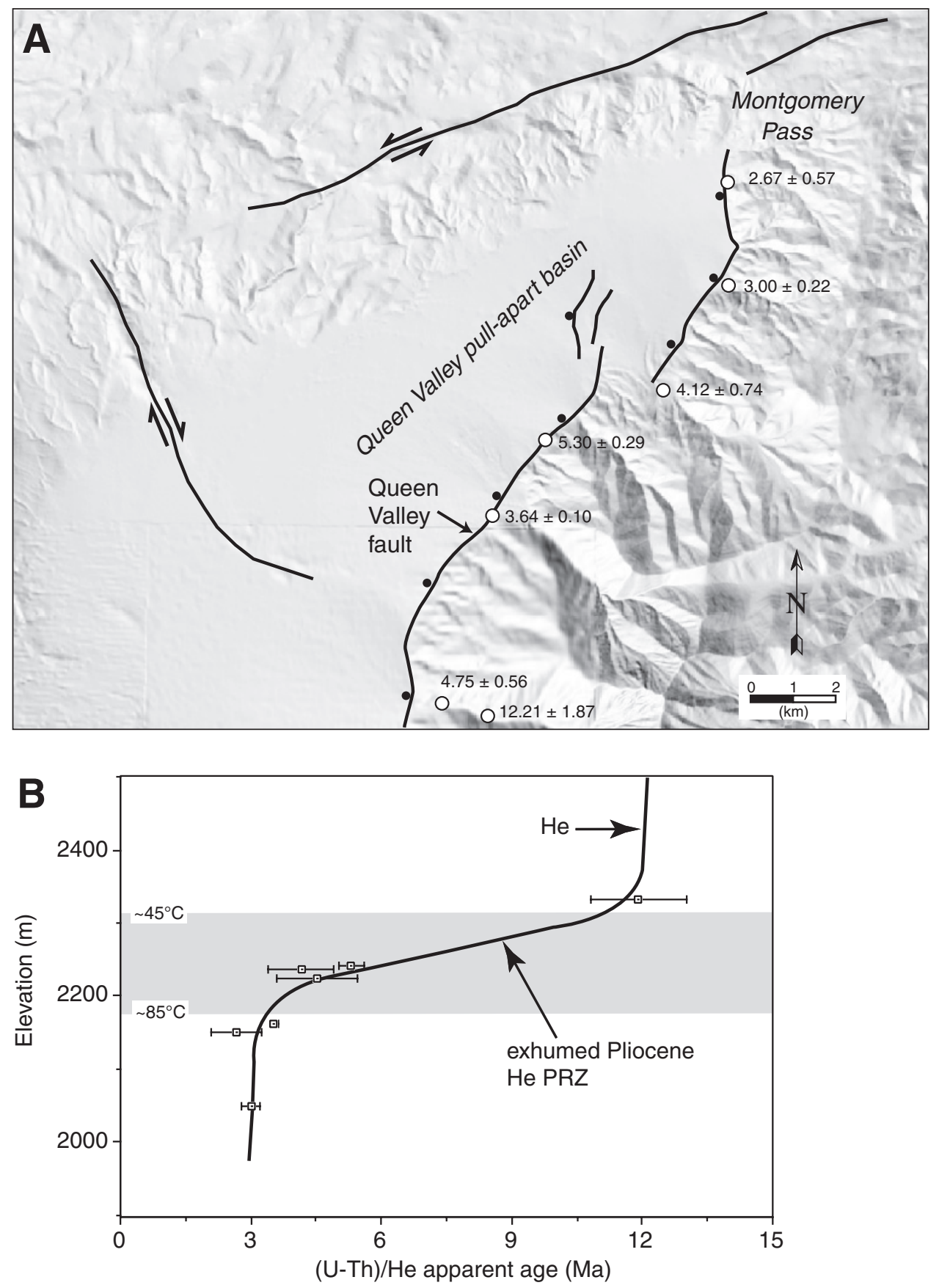

Figure 13. (A) Digital shaded relief of the northernmost White Mountains and Queen Valley area showing major Cenozoic faults and apatite (U-Th)/He data from the footwall of the Queen Valley fault. (B) Apatite (U-Th)/He data from samples in the footwall of the Queen Valley fault showing typical apparent age versus elevation behavior with an inflection point at $\sim 2200 \mathrm{~m}$, which directly dates the onset of NW-directed extension at ca. 3 Ma. PRZ-partial retention zone. Modified from Stockli et al. (2000).
EW-striking thrust fault and/or fold that cuts late Cenozoic basalt lava and Qf1 and Qf2 surfaces (Figs. 12, 15, 16, and 17).

Topographic profiling, using differential global positioning system (GPS) data, of normal fault scarps developed within Qcf2, Qcf3, and Qf2 surfaces yields a minimum net vertical surface offset of $>16.6 \mathrm{~m}$ and $\sim 6.1 \mathrm{~m}$ (Figs. 15 and 16), indicating a minimum vertical slip rate of $\sim 0.3 \mathrm{~mm} / \mathrm{yr}$ since ca. $52.2 \mathrm{ka}$ and a maximum vertical slip rate of $\sim 0.5 \mathrm{~mm} / \mathrm{yr}$ since ca. $13.5 \mathrm{ka}$ (note the slip rates do not significantly change if we use ${ }^{10} \mathrm{Be}$ model ages that incorporate erosion). Assuming these normal faults dip $60^{\circ}$ yields a horizontal extension rate of $\sim 0.2 \mathrm{~mm} / \mathrm{yr}$. GPS measurement of left-laterally offset channel walls in a Qf2 surface yields an estimated sinistral offset of $\sim 50.4 \mathrm{~m}$, indicating a minimum sinistral slip rate of $\sim 0.7 \mathrm{~mm} / \mathrm{yr}$. Measurable offset markers are not present across the NW-striking dextral and EW-striking thrust faults.

\section{Kinematics of Fault Slip Transfer}

The Queen Valley normal fault, as well as other major NE-striking, NW-dipping normal faults such as the Deep 

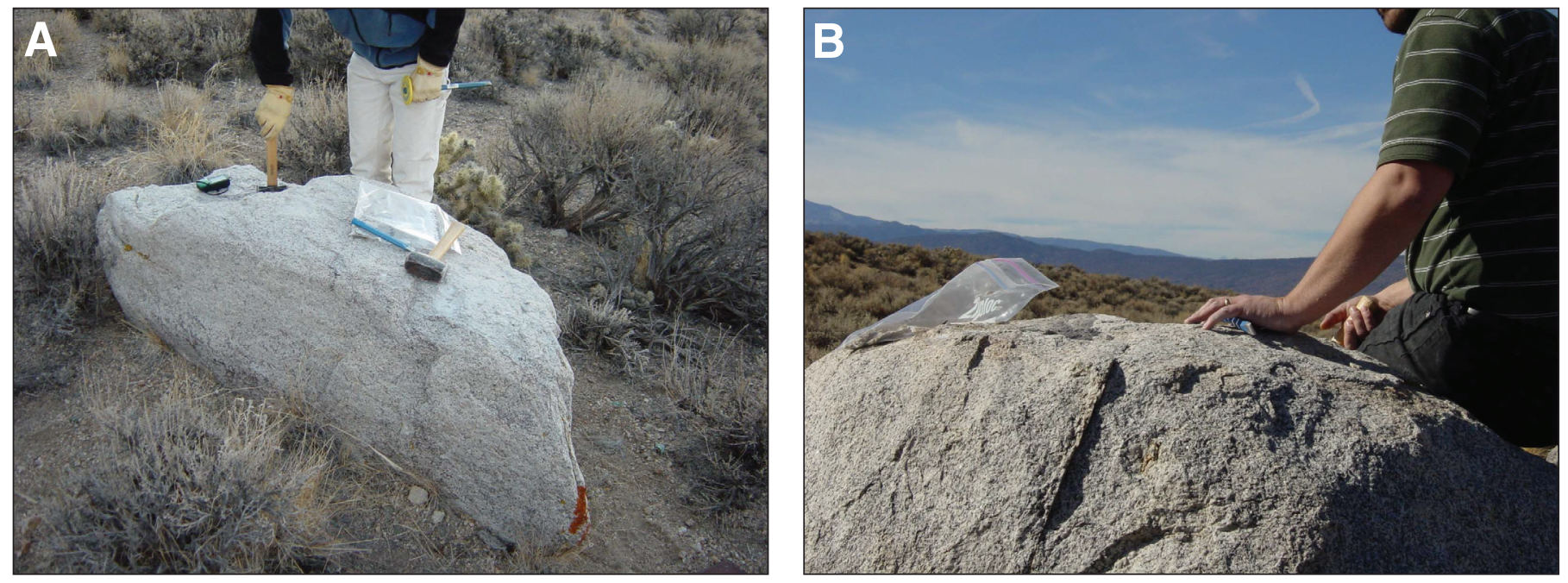

Figure 14. Photographs of representative granite boulders from Queen Valley sampled for cosmogenic radionuclide (CRN) geochronology. (A) Boulder on a Qf3c surface in the hanging wall of Orchard Spring fault (see Fig. 15). (B) Boulder on a Qf2 surface.

Springs and Towne Pass faults, define right steps and transfer slip between the White Mountains-Owens Valley, Hunter Mountain-Panamint Valley, Death Valley-Furnace Creek-Fish Lake Valley, and Benton Springs-Petrified Springs fault zones (Fig. 2). Right steps in the Death Valley and Hunter MountainPanamint Valley fault zones are associated with the Death Valley and Panamint Valley pull-apart basins, respectively (Burchfiel et al., 1987; Burchfiel and Stewart, 1966; Oswald, 1998), and Queen Valley is analogous to these larger basins. However, in contrast to the Death Valley and Panamint Valley pull-apart basins, Queen Valley does not simply define a right-stepping extensional-step between two dextral fault systems. Rather, the Queen Valley normal fault connects the dextral White Mountains fault zone with the sinistral Coaldale fault (see below), which in turn connects to the dextral Benton Springs and Petrified Springs faults (Figs. 3, 18, and 19).

The development of the geometry and type of structures in the Queen Valley region can be described best by a strike-slip shear couple. Predictable fault and fold geometries have been observed both in experiments and in the field in zones characterized by simple shear (Fig. 18) (e.g., Wilcox et al., 1973; Sylvester, 1988). As illustrated in Figure 18, a simple shear diagram, with the shear couple parallel to the White Mountains fault zone, predicts well the geometry and type of major faults in the Queen Valley area. Using this simple shear diagram as a framework, we suggest that $\leq 1.5 \mathrm{~mm} / \mathrm{yr}$ of dextral slip from the White Mountains fault zone is transferred onto three faults with different geometries and senses of motion, and is partitioned into three nearly equal components: $\sim 0.2 \mathrm{~mm} / \mathrm{yr}$ horizontal extension along the NW-dipping Queen Valley normal fault, $\sim 0.5 \mathrm{~mm} / \mathrm{yr}$ sinistral slip along the ENE-striking Coaldale fault, and the remaining $\leq 0.6 \mathrm{~mm} / \mathrm{yr}$ dextral slip along the NW-striking Coyote Springs fault (Fig. 18).

\section{EASTERN QUEEN VALLEY VOLCANIC STRATIGRAPHY}

Cenozoic volcanic rocks exposed within the northern White Mountains area unconformably overlie Paleozoic metasedimentary rocks and Jurassic-Cretaceous granodiorite (Crowder et al., 1972). Throughout the Queen Valley area, a heavily oxidized marble conglomerate marks the base of the Tertiary volcanic sequence. Based on field mapping of numerous fault exposures throughout the area, the Tertiary stratigraphy can be subdivided into four main units (Tincher, 2005) (Figs. 20 and 21): (1) Brownie Creek rhyolite (Trb), possibly associated with

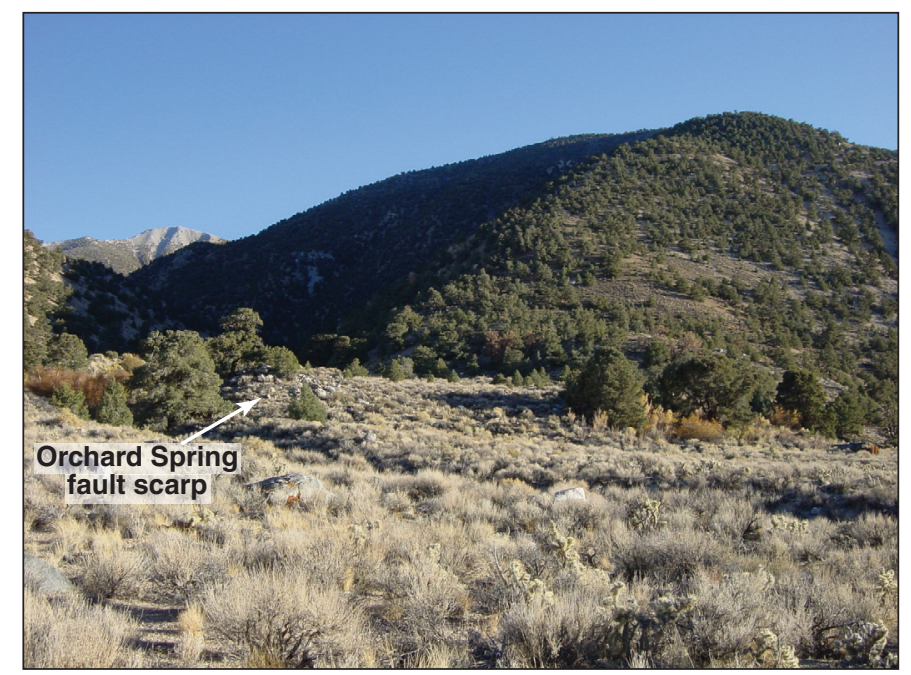

Figure 15. Photograph of Orchard Spring normal fault scarp. Qf3c alluvial fan surface in the hanging wall and Qf2 surface in the footwall. View to southeast. 
Profile 1

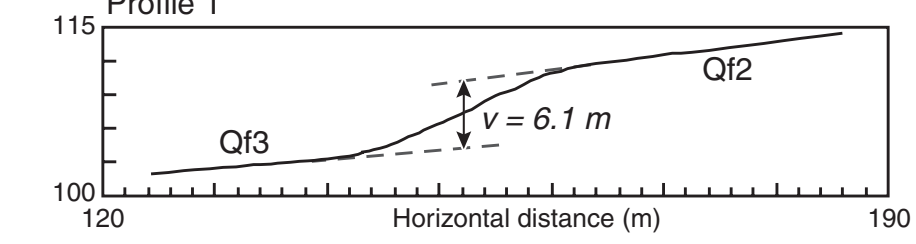

Profile 2

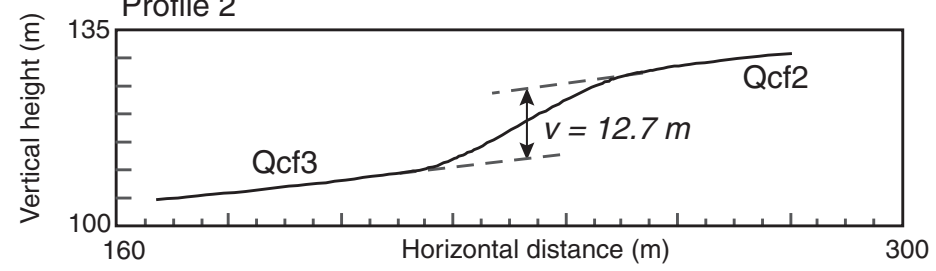

Profile 3

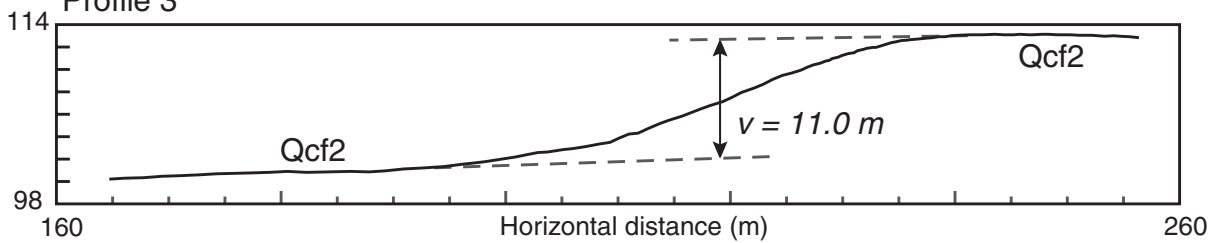

Figure 16. Representative scarp profiles showing vertical offset (v) of alluvial fan surfaces. Profile 1 is across the Orchard Spring normal fault scarp shown in Figure 15.

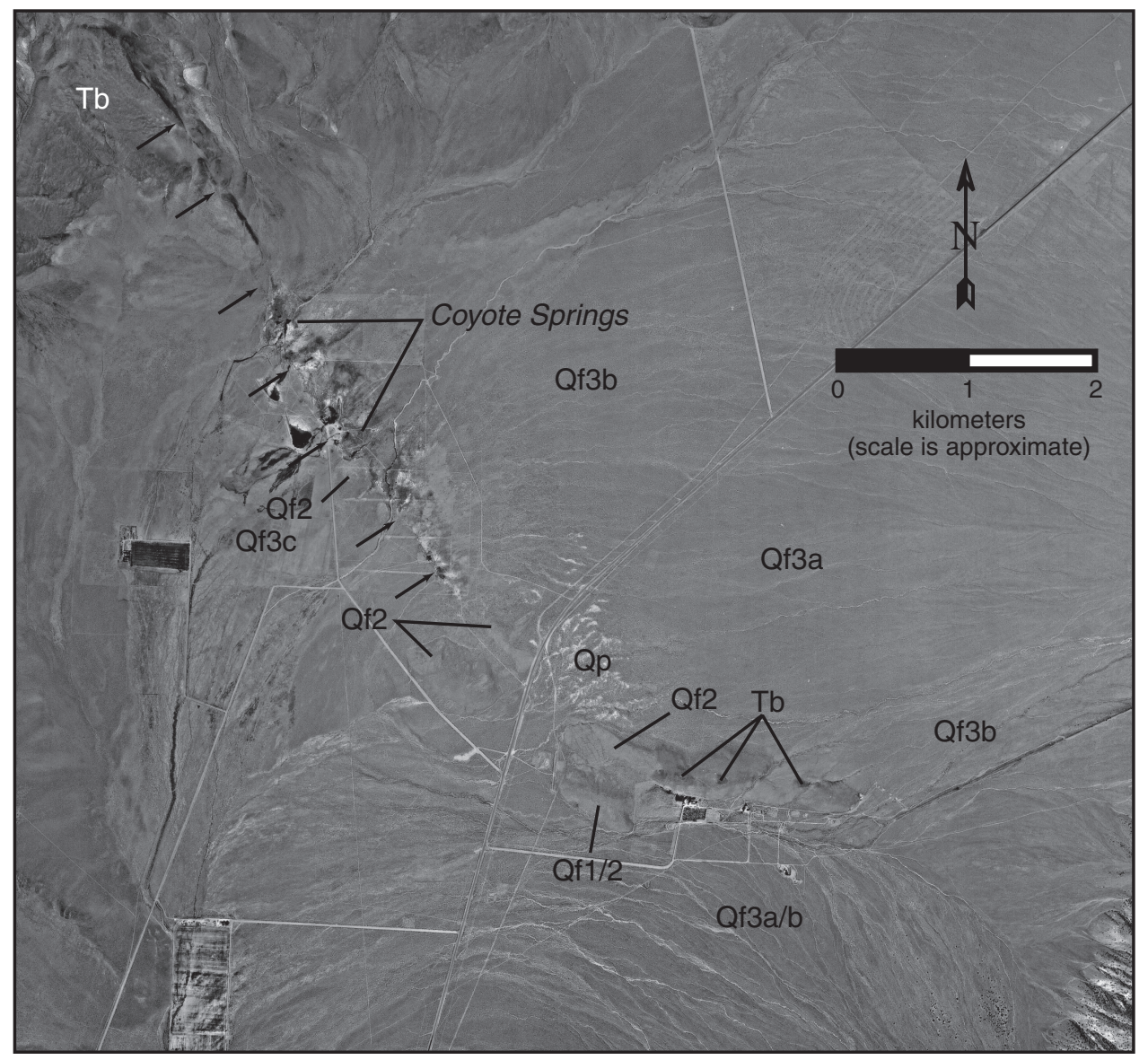

Figure 17. Aerial photograph of the southwest part of Queen Valley showing Tertiary basalt lavas (Tb) and Qf1, Qf2, and Qf3 alluvial fan surfaces cut by a NW-striking dextral fault (highlighted by arrows), which we informally refer to as the Coyote Springs fault. This fault merges to the SE into a set of NE- to EW-trending hills interpreted to be either an antiform and/or the hanging wall of a north-dipping thrust fault. 


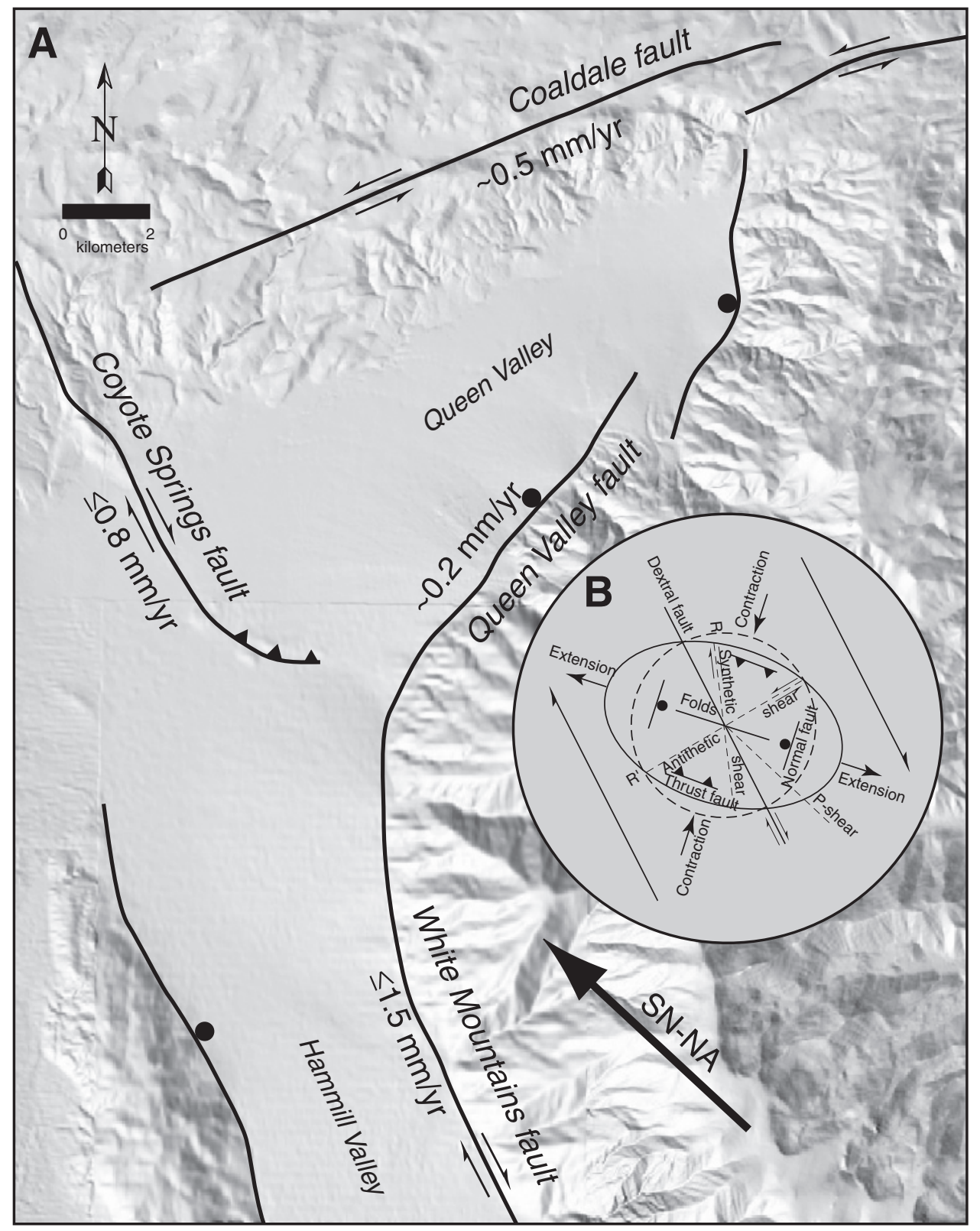

Figure 18. (A) Shaded relief map of the Queen Valley region highlighting the major Quaternary faults and estimated horizontal slip rates. Large arrow indicates motion of the Sierra Nevada microplate $(\mathrm{SN})$ with respect to the fixed North American plate (NA). (B) Geometry and style of faults and folds that can develop within a strike-slip shear couple. Shear couple is parallel to the strike of the White Mountains fault zone, resulting in predicted faults that are nearly parallel to those observed in the Queen Valley region.

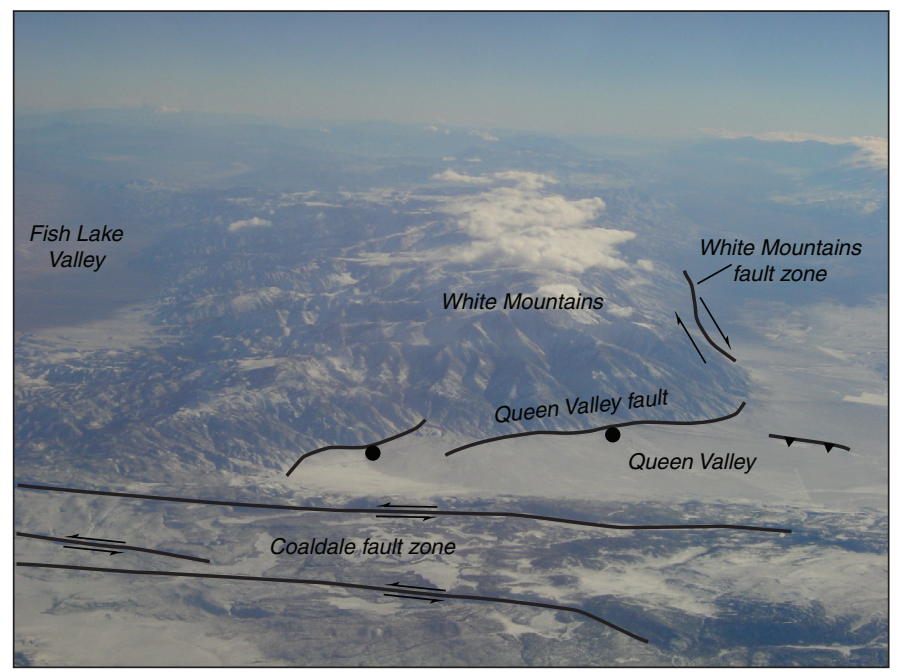

Figure 19. Aerial photograph of the northern end of the White Mountains and Queen Valley. Major active faults in the region are highlighted. Solid circles are on the hanging wall of normal faults; solid teeth are on the hanging wall of thrust faults; arrows indicate relative motion across strike-slip faults. View is to south. 
widespread Oligocene ash-flow tuffs found in western Nevada; (2) Miocene andesite (Ta), possibly correlated to 10-15 Ma lavas found throughout the central Walker Lane Belt; (3) rhyolite of Sugarloaf Canyon ( $\mathrm{Tr}$ ), which is similar to ca. $6 \mathrm{Ma}$ (K/Ar age) rhyolites found in the Silver Peak Range (Robinson et al., 1968); and (4) basalt of Mount Montgomery (Tb), which is similar to ca. $3 \mathrm{Ma}(\mathrm{K} / \mathrm{Ar}$ age) basalts found in the Benton Range (Dalrymple and Hirooka, 1965).

\section{Brownie Creek Rhyolite}

${ }^{40} \mathrm{Ar} /{ }^{39} \mathrm{Ar}$ radiometric dating of sanidine from the Brownie Creek rhyolite yielded an age of $25.75 \pm 0.06 \mathrm{Ma}$ (Fig. 20). Three of fifteen sanidine crystals analyzed were not included in the calculation due to their comparatively large ${ }^{36} \mathrm{Ar} /{ }^{39} \mathrm{Ar}$ ratio and subsequent low amount of radiogenic Ar released. This age is consistent with the age of widespread ash-flows reported by Robinson and Stewart (1984) and Petronis (2005) from the nearby Candelaria Hills volcanic center.

\section{Miocene Andesite}

Previous work on this unit is limited to regional studies, which have described andesite flows in the central Walker Lane Belt with K/Ar ages of 15-20 Ma (Hardyman and Oldow, 1991) and in the northern White Mountains with ${ }^{40} \mathrm{Ar} /{ }^{39} \mathrm{Ar}$ ages of ca. $12 \mathrm{Ma}$ (Stockli et al., 2003). Zircon (U-Th)/He data from unaltered andesite samples yield a mean age of $12.6 \pm 1.0 \mathrm{Ma}$, suggesting a mid-Miocene age similar to andesite flows in the northern White Mountains (Stockli et al., 2003). The andesites are in unconformable contact with both underlying and overlying rhyolite units (Figs. 20 and 21).

\section{Rhyolite of Sugarloaf Canyon}

Samples collected from several cooling units within the rhyolite of Sugarloaf Canyon were dated using (U-Th)/He on selected zircon and titanite grains. Five samples yielded mean zircon (U-Th)/He ages of $5.5 \pm 0.3 \mathrm{Ma}, 5.5 \pm 1.1 \mathrm{Ma}, 5.4$ $\pm 0.2 \mathrm{Ma}, 5.4 \pm 0.8 \mathrm{Ma}$, and $5.66 \pm 0.03 \mathrm{Ma}$. In addition, two samples were analyzed using single-grain titanite and yielded ages of $5.5 \pm 0.9 \mathrm{Ma}$ and $5.0 \pm 0.7 \mathrm{Ma}$ (Fig. 20). Radiometric age results are in good agreement with stratigraphic position; the highest stratigraphic sample yields the youngest age at 5.0 $\pm 0.7 \mathrm{Ma}$ whereas the lowest stratigraphic sample yields an age of $5.5 \pm 0.3 \mathrm{Ma}$ (Fig. 20).

\section{Basaltic of Mount Montgomery}

Two samples taken from approximately the same cooling unit within the basalt of Mount Montgomery yielded whole rock ${ }^{40} \mathrm{Ar} /{ }^{39} \mathrm{Ar}$ ages of $3.14 \pm 0.03$ and $3.35 \pm 0.15 \mathrm{Ma}$. A third sample was taken from a much lower part of the section and yielded a whole rock ${ }^{40} \mathrm{Ar} /{ }^{\beta 9} \mathrm{Ar}$ age of $4.08 \pm 0.10 \mathrm{Ma}$ (Fig. 20).
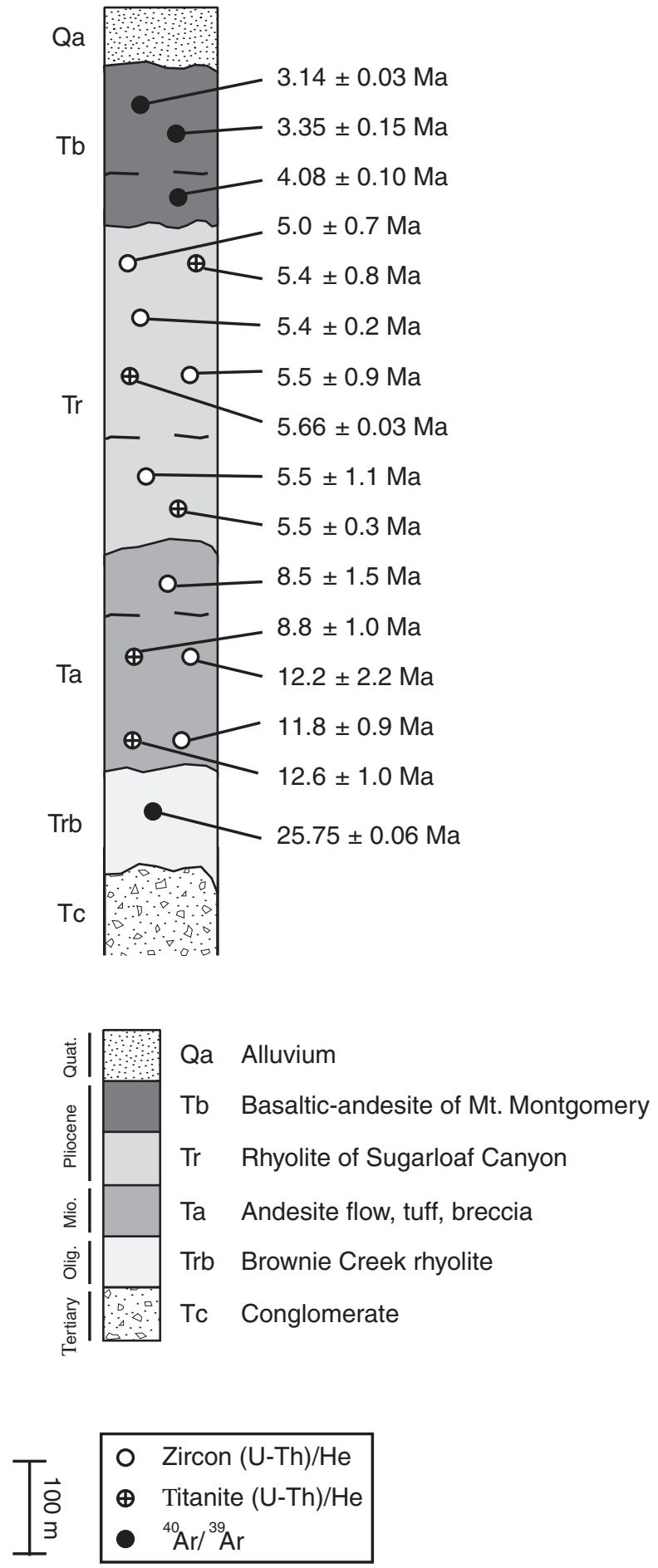

Figure 20. Composite Tertiary volcanic stratigraphy of the eastern Queen Valley area. Solid circles denote new ${ }^{40} \mathrm{Ar} /{ }^{39} \mathrm{Ar}$ age data; hollow circles denote zircon (U-Th)/He age data; crossed-circles denote titanite (U$\mathrm{Th}) / \mathrm{He}$ age data (all errors are $1 \sigma$ ). Modified from Tincher (2005). 


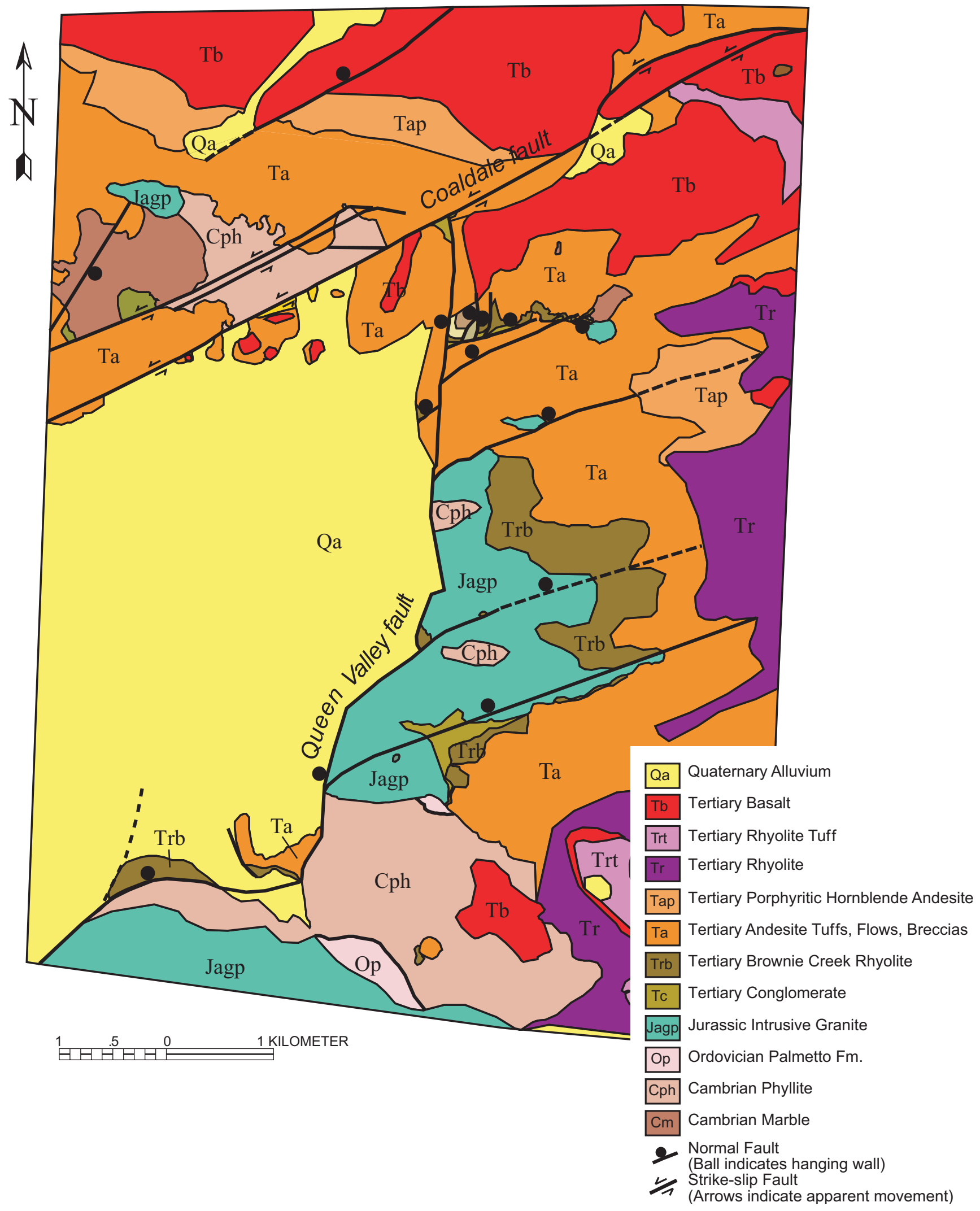

Figure 21. Bedrock geologic map of the northernmost White Mountains and eastern portion of Queen Valley. Modified from Tincher (2005). 


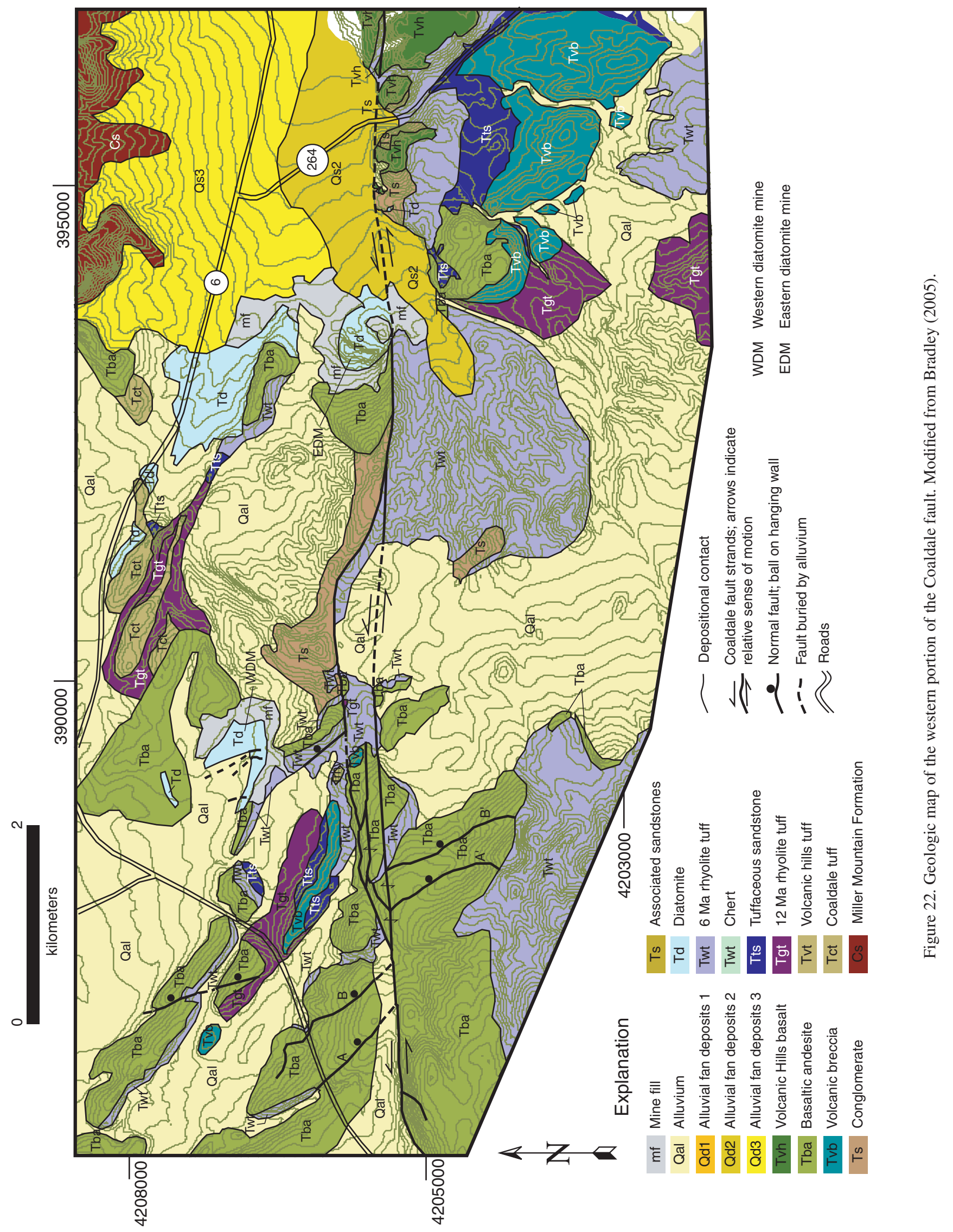




\section{COALDALE FAULT}

In the southwestern Mina deflection, the left-lateral Coaldale fault links the Queen Valley and Columbus Salt Marsh pullapart structures at its eastern and western extents in a geometry similar to the Excelsior fault (e.g., Stockli et al., 2003). The Queen Valley normal fault extends eastward of the Queen Valley pull-apart structure to merge with the left-lateral Coaldale fault (Figs. 3 and 21). Although brittle kinematic indicators and exposed fault planes are sparse along the trace of the Coaldale fault system, offset geologic markers and strike-slip geomorphology indicate a left-lateral slip sense. As the Coaldale fault is followed eastward from Montgomery Pass, the fault is locally poorly exposed until it reaches a large deposit of Pliocene basalt at Volcanic Hills, where it is well defined as a series of subparallel, $\sim$ EW-striking fault segments. Farther east, the fault is obscured by alluvial fill as it enters the Columbus Salt Marsh pull-apart basin (Figs. 22, 23, 24, and 25).

Tectonic geomorphology provides the best constraint on the geometry and kinematics of the Coaldale fault system. Offset geologic marker units and structures, beheaded stream drainages, and shutter ridges indicate a left-lateral slip sense despite the lack of brittle kinematic indicators. The ages of offset markers have been derived radiometrically or can be bracketed by stratigraphically bounding units and/or cross cutting relationships.

\section{Western Portion of The Coaldale Fault}

The surface expression of the Coaldale fault is an EW-trending linear valley bounding a large deposit of basaltic andesite $\left(5.28 \pm 0.01 \mathrm{Ma}\right.$; whole rock $\left.{ }^{40} \mathrm{Ar} /{ }^{39} \mathrm{Ar}\right)$ in the westernmost portion of the study area (Figs. 22 and 24). The fault can be recognized as a ridge traversing the deposit of basaltic andesite as it is traced eastward. Directly east of two truncated east-dipping normal faults, the Coaldale fault splits into three fault strands (Figs. 22 and 24). The northern strands are subsidiary faults that splay slightly to the ENE, while the southernmost fault represents the main strand of the Coaldale fault. The main strand of the fault continues along the original EW trend. Smaller fault segments splay from both the subsidiary and main fault trace, but they are not thoroughgoing structures. At the westernmost part of the map area, in the Montgomery Pass region, a basalt cinder deposit erupted from a $3.14 \pm 0.03 \mathrm{Ma}\left({ }^{40} \mathrm{Ar} /{ }^{39} \mathrm{Ar}\right.$ whole rock) basalticandesite cone has been left laterally offset $\sim 1.2 \mathrm{~km}$ (Fig. 26).

\section{Coaldale Fault Main Strand}

The main strand of the Coaldale fault is traced from the bifurcation of the subsidiary splays eastward by a ridge in the basaltic andesite. The fault left-laterally offsets a portion of this deposit by $\sim 650 \mathrm{~m}$ (Figs. 22 and 23 ) and projects eastward from the edge of the basaltic andesite, beneath Quaternary alluvium, to intersect the southern tip of the eastern diatomite mine (Figs. 22

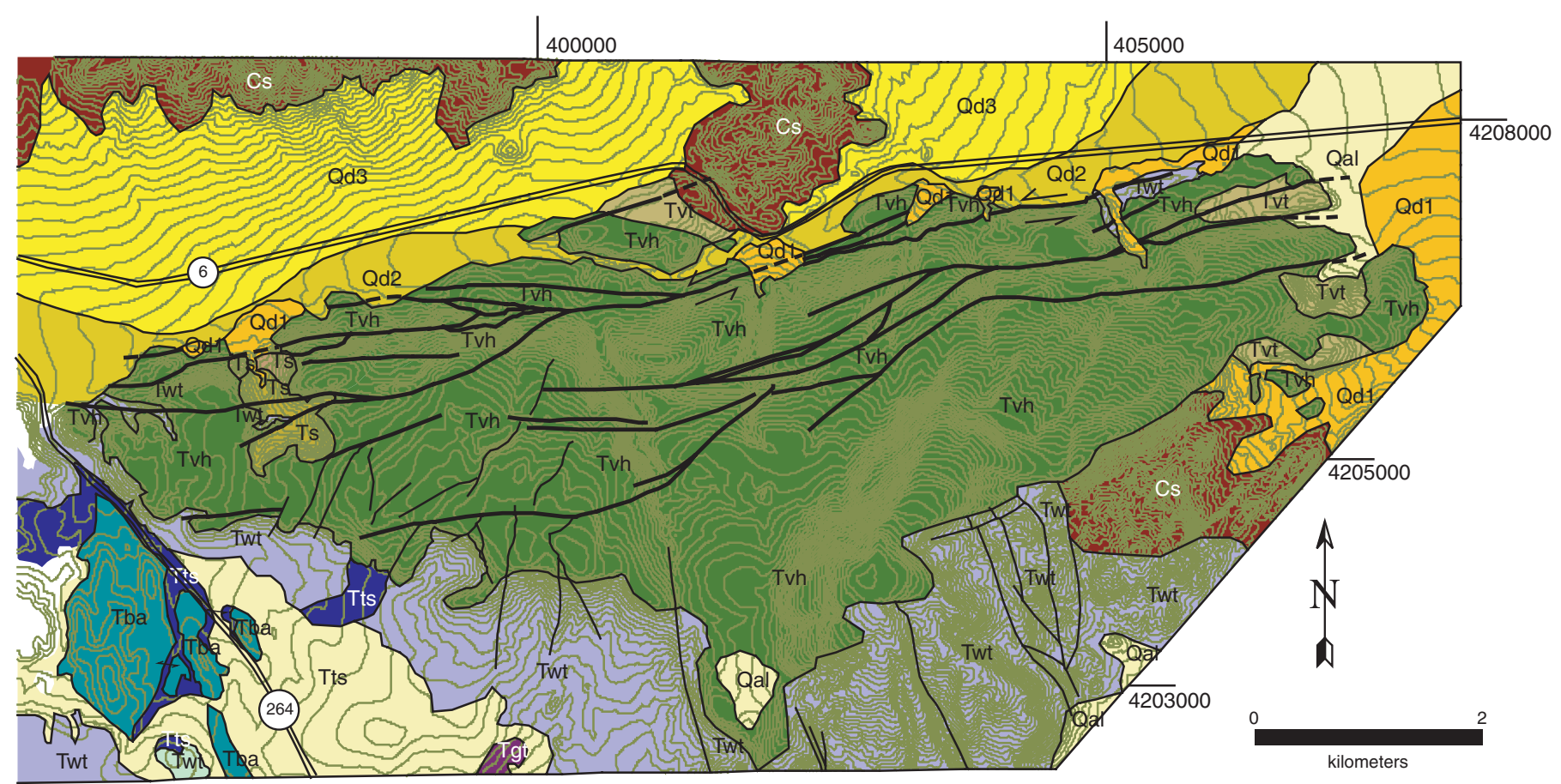

Figure 23. Geologic map of the Volcanic Hills area along the eastern portion of the Coaldale fault. Modified from Bradley (2005). See Figure 22 for legend. 

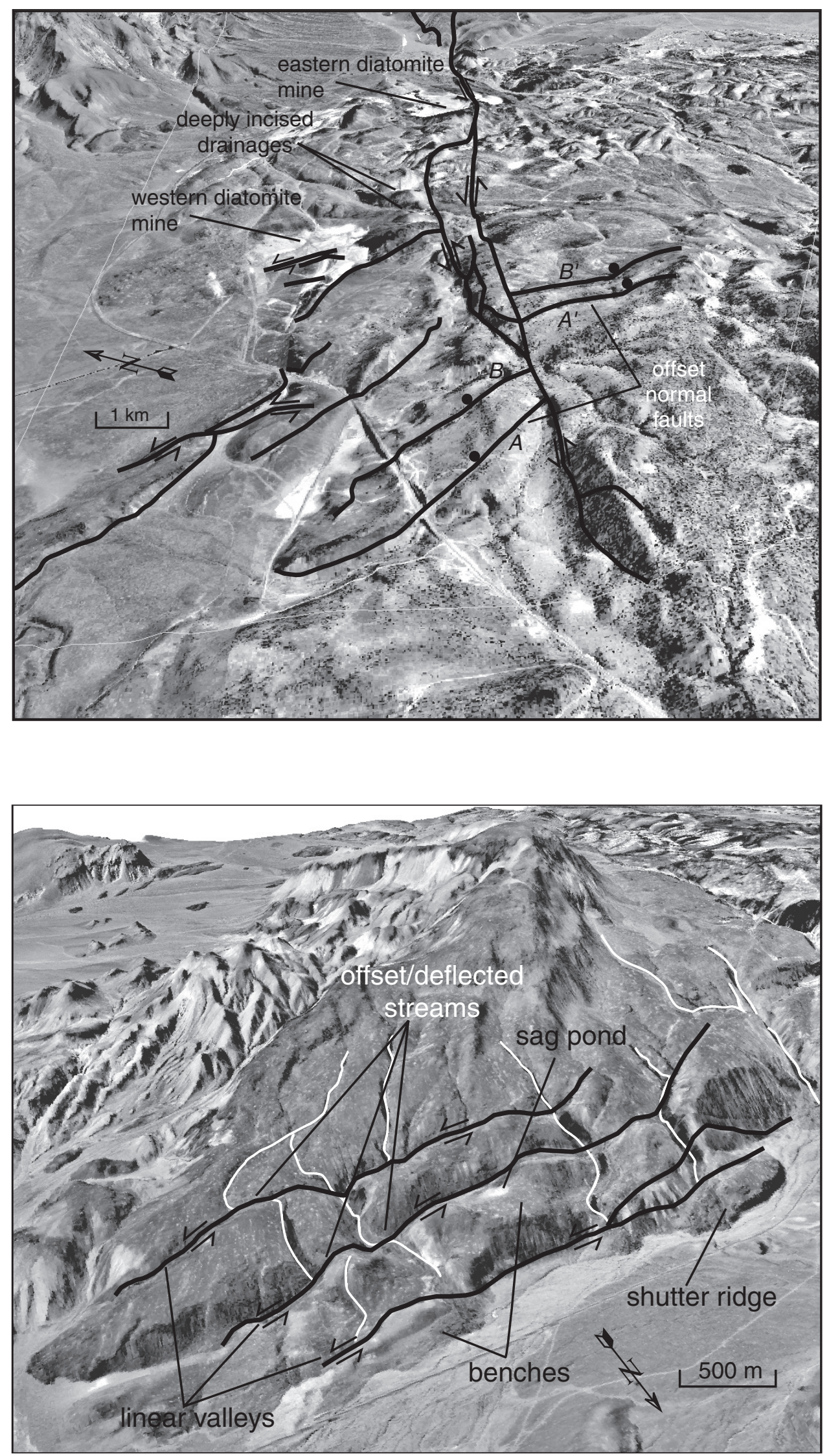

Figure 24. Digital three-dimensional oblique aerial view of the central Coaldale fault. The Coaldale fault (just right of center) truncates and left-laterally offsets two normal faults, A and B, for $\sim 1 \mathrm{~km}$. Digital U.S. Geological Survey orthophotographic quadrangle maps draped over high resolution digital elevation model. View is to the ENE. Modified from Bradley (2005).
Figure 25. Digital three-dimensional oblique aerial view of the eastern Volcanic Hills area. Digital U.S. Geological Survey orthophotographic quadrangle maps draped over high resolution digital elevation model with major fault strands and geomorphologic features highlighted. View is to the SW. Modified from Bradley (2005). 
and 24). Here, diatomite is tilted as much as $90^{\circ}$. Most diatomite within the eastern diatomite mine is well-bedded, consistently striking $\sim$ NS with moderate dips $\left(<25^{\circ}\right)$. Proximal to the projection of the Coaldale fault, the strike of the bedding abruptly rotates through nearly $90^{\circ}$, and its dip steepens to $>45^{\circ}$. A large deposit of basaltic andesite $\left(4.7 \pm 0.9 \mathrm{Ma}\right.$; whole rock $\left.{ }^{40} \mathrm{Ar} /{ }^{39} \mathrm{Ar}\right)$ capping the eastern diatomite mine is sinistrally offset $\sim 1 \mathrm{~km}$ (Figs. 22 and 24). From the eastern diatomite mine, the Coaldale fault projects eastward beneath Quaternary alluvium to intersect the EW-striking fault scarps in western Volcanic Hills (Figs. 22, 23,24 , and 25).

\section{Subsidiary Fault Strand}

A subsidiary fault can be projected eastward where it intersects a deposit of basaltic andesite directly south of the western diatomite mine. This strand left-laterally offsets a portion of this deposit $\sim 250 \mathrm{~m}$ (Figs. 22 and 24). The subsidiary fault can be traced from this offset lobe eastward to where it truncates deeply incised stream drainages. The fault subsequently defines a series of right-steps as the strike changes to ESE (Fig. 22). The rightstep creates a local transpressional structure that has uplifted and tilted a deposit of well-bedded conglomerate. The dip of the conglomerate unit is $\sim 15^{\circ} \mathrm{NW}$ directly west of the right-step, whereas the dip varies between $30^{\circ}$ and $65^{\circ} \mathrm{NE}$ directly east of the right-step. The fault continues ESE from the transpressional structure to intersect the main strand of the Coaldale fault south of the eastern diatomite mine (Fig. 22).

\section{Coaldale Fault in Volcanic Hills}

The northern flank of Volcanic Hills is characterized by thick deposits of late Pliocene basalt ( $3.14 \pm 0.1 \mathrm{Ma})$, a sharp contrast to the diverse stratigraphy and extensive alluvial fill found to the west (Figs. 23, 25, and 27). Within this unit, the Coaldale fault system is exposed as a complicated array of EW- and ENE-striking fault scarps. Examples of tectonic geomorphology, such as deflected stream drainages, shutter ridges, sag ponds, and offset lobes of basalt, indicating a left-lateral slip sense, are pervasive throughout the area (Figs. 23 and 25).

The Coaldale fault is exposed in an EW-trending linear valley on the western edge of Volcanic Hills. A linear fault scarp traverses basalt capping Volcanic Hills from the valley's easternmost termination into a large, NS-trending stream drainage. Directly east of the drainage, the Coaldale fault steps left from an EW trend to an ENE trend, creating a local releasing structure. The left-step in the fault system is characterized by a complicated array of ENE-striking subparallel fault scarps that merge with EW-striking fault scarps in an en echelon pattern (Fig. 23). Blocks of basalt within the bend are vertically down-dropped and left-laterally offset. Field mapping and three-dimensional imaging show that the EW-striking fault scarps within the bend are predominantly left-lateral, while the connecting ENE-striking fault segments are predominately dip-slip. The faults merge directly east of the left-step and return to the original EW-strike.

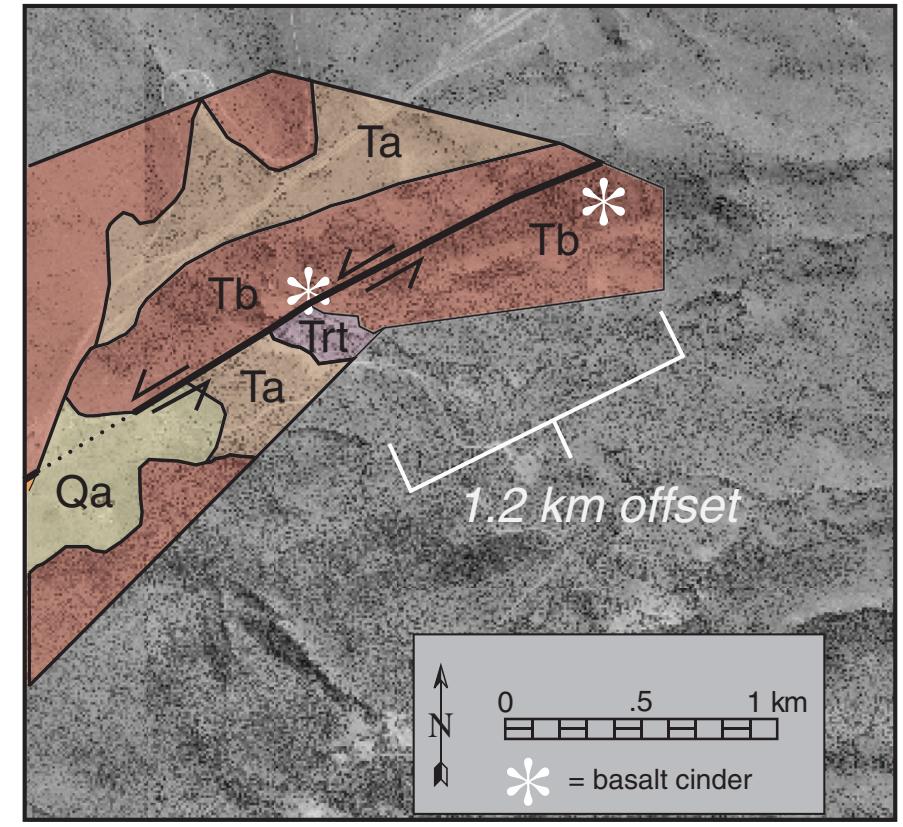

Figure 26. Schematic map of the Montgomery Pass area. Basaltic-andesite cinder is left-laterally offset $\sim 1.2 \mathrm{~km}$ across the Coaldale fault. This measurement, combined with an ${ }^{40} \mathrm{Ar} /{ }^{39} \mathrm{Ar}$ age of $3.14 \pm 0.03 \mathrm{Ma}$ for the basaltic-andesite, yields a minimum Pliocene fault slip rate of $\sim 0.4 \mathrm{~mm} /$ $\mathrm{yr}$ along this part of the Coaldale fault. There is no evidence for active fault scarps in the Quaternary alluvium found at Montgomery Pass.

The EW-striking fault scarps that emerge from the local releasing bend swing to an ENE orientation in central Volcanic Hills. The ENE-striking fault scarps left-laterally offset stream drainages and lobes of basalt (Fig. 23).

In eastern Volcanic Hills, the Coaldale fault system is characterized by the original $\sim$ EW-strike observed throughout the majority of the study area and impressive examples of strike-slip tectonic geomorphology (Fig. 25). Two distinct EW-trending linear valleys, interpreted as ancient fault strands, offset NS-trending stream drainages. A sag pond and bench pair, indicative of a strike-slip faulting, are present between the two linear valleys. Exposed on the northern flank of eastern Volcanic Hills are high angle, well defined fault scarps and a shutter ridge, indicating the most recently active fault strand (Fig. 25).

\section{Offset Magnitudes and Fault Slip Rates}

We estimated left-lateral displacement along the Coaldale fault system and subsidiary faults by measuring distances between correlative offset geologic marker units, structures, and geomorphic features (Fig. 28). The ages of offset geologic volcanic units were radiometrically determined wherever possible (Fig. 27). Ages of offset structures, geomorphic features, and sedimentary units were bracketed by stratigraphically bounding volcanic units and/or cross-cutting relationships. In the case in which an offset 


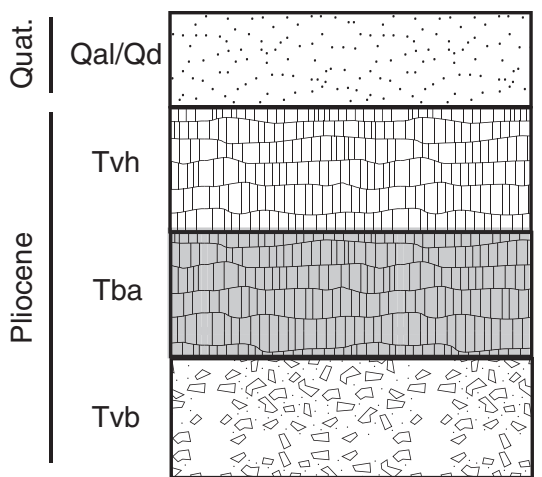

Angular unconformity $<1 \mathrm{Ma}$

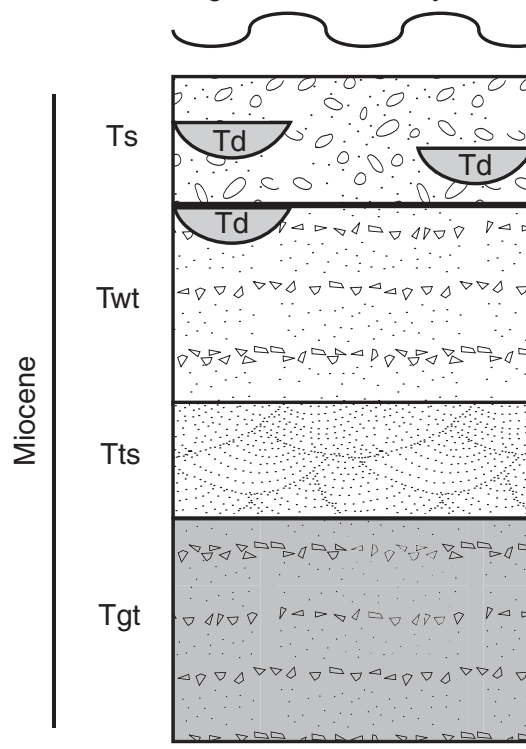

Unconformity $\sim 12 \mathrm{Ma}$

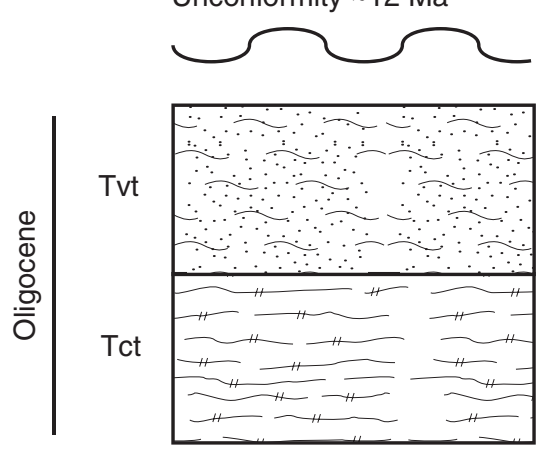

Unconformity $\sim 500 \mathrm{Ma}$

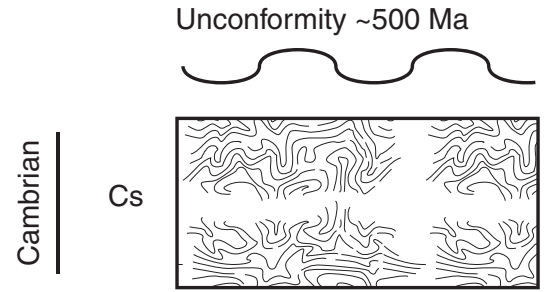

Quaternary alluvium including Qd1, Qd2, and Qd3

Basalt lava $\left(3.51 \pm 0.39 \mathrm{Ma}^{*}\right)$

Basaltic-andesite lava $\left(5.2 \pm 0.4 \mathrm{Ma}^{*}\right)$

Andesitic volcanic breccia

Sedimentary rocks with diatomite

White rhyolite tuff $\left(6.3 \pm 0.1 \mathrm{Ma}^{\#}\right)$ with diatomite

Fluvially reworked tuffaceous sandstone

Gray rhyolite tuff $\left(12.0 \pm 0.3 \mathrm{Ma}^{\#}\right)$

Volcanic hills tuff $\left(23.4 \pm 1.0 \mathrm{Ma}^{\$}\right)$

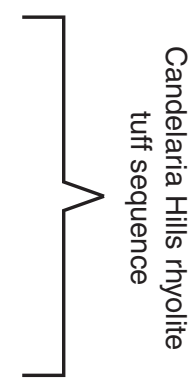

Coaldale tuff $\left(31.0 \pm 1.5 \mathrm{Ma}^{\#}\right)$

Paleozoic sedimentary and

metasedimentary rocks, undifferentiated

Figure 27. Composite stratigraphic column for the Coaldale fault region. Geochronologic methods used include ${ }^{40} \mathrm{Ar} /{ }^{39} \mathrm{Ar}$ whole rock (*), (U-Th)/He on titanite (\#), and $\mathrm{K}-\mathrm{Ar}(\$)$. 


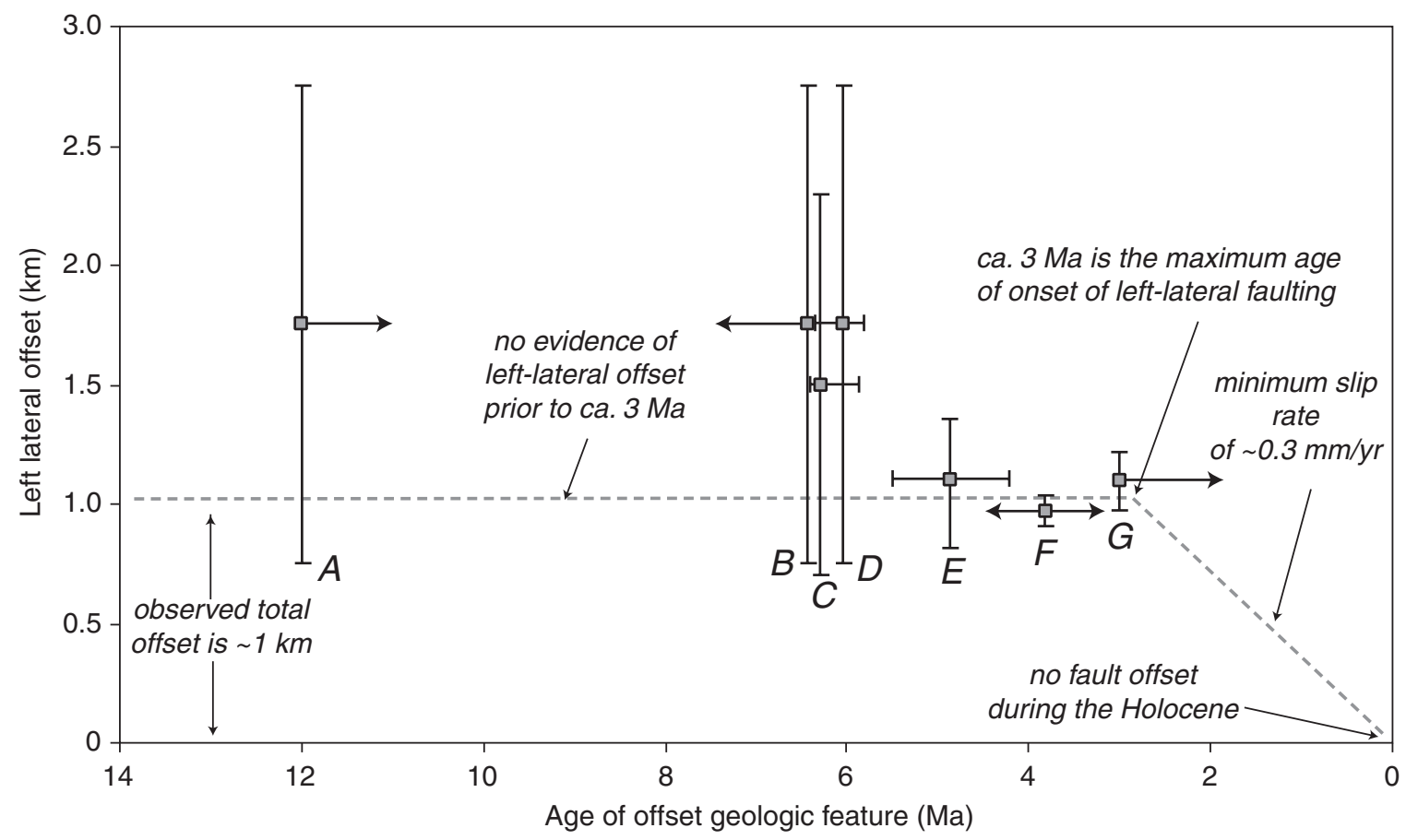

Figure 28. Summary of ages and displacement of left-laterally offset geologic markers along the Coaldale fault. A-lower boundary of tuffaceous sandstone; B — upper boundary of tuffaceous sandstone; C — conglomerate; D — andesite volcanic breccia; E-basaltic-andesite lava; F-normal faults A and B; G-cumulative measured offset streams and basalt lobes in Volcanic Hills. Based on these data, along with estimated age for onset of normal faulting in Queen Valley, ca. 3 Ma is our preferred age for onset of left lateral faulting. Maximum observed left lateral offset of $\sim 1 \mathrm{~km}$ yields a minimum slip rate of $\sim 0.3 \mathrm{~mm} / \mathrm{yr}$.

geologic unit is spatially distant from the Coaldale fault due to post-faulting erosion, the unit has been extended to intersect the fault. The angle used to extend the unit was the mean strike of bedding. In addition, several volcanic flows, normal faults, and geomorphic features directly intersect and are truncated by the Coaldale fault at high angles. Based on 14 correlative offset features throughout the area, the Coaldale fault preserves $\sim 0.85$ $1.2 \mathrm{~km}$ of left-lateral displacement $(\sim 1 \mathrm{~km})$ since ca. $3 \mathrm{Ma}$, yielding a minimum slip rate of $\sim 0.3-0.4 \mathrm{~mm} / \mathrm{yr}$ (Fig. 28).

\section{FIELD GUIDE}

This field guide does not give explicit directions and mileages for each mile of the trip; instead, stops are located relative to local towns and landmarks. Approximate locations of field trip stops are shown in Figure 3.

\section{Stop 1: White Mountains Fault Zone}

Getting there: This stop is between Coldwater Canyon and Gunter Creek, 10 mi north of the town of Bishop. Drive north on Highway 6 from the intersection with Wye Road at the northern end of Bishop for 7.3 mi to the intersection with Rudolf Road. Turn right (east) and continue on this road for $\sim 0.5 \mathrm{mi}$. Turn left ( $\sim$ north) onto a dirt road and continue for $\sim 1.1 \mathrm{mi}$ and park on the right side of the road. We will walk up to the top of the hill to the south $\left(37.5643^{\circ} \mathrm{N}, 118.3287^{\circ} \mathrm{W}\right)$.

This region exposes the maximum measured dextral offset across the White Mountains fault zone (Figs. 4, 9, and 10). This highly dissected ridge and ravine morphology is characteristic of Qf1a surfaces. Just to the south of this hill, note the less welldeveloped ridge and ravine morphology of a Qf1b surface inset into this Qf1a surface. The White Mountains fault zone is located to the east at the base of the Qf1a hill and is buried by a Qf3a surface. The fault trace continues to the south and east of the inset Qf1b surface and then west of the Qf1b surface located to the southeast of the paved road. Three beheaded/betailed stream channel pairs, C2a, C2b, and C2c, are incised into Qf1a and Qf1b fan surfaces on both sides of the fault. Restoring the offset of each channel yields $\sim 492 \mathrm{~m}$ of dextral slip across this trace of the fault (Figs. 9 and 10). Dextral offset of channel C1, the deeply incised channel immediately to the south of the top of the Qf1a hill is $\sim 358 \mathrm{~m}, \sim 135 \mathrm{~m}$ less than channels $\mathrm{C} 2 \mathrm{a}, \mathrm{C} 2 \mathrm{~b}$, and C2c, possibly because it is younger and, therefore, has not been dextrally offset to the same degree. Apparent vertical offset (west-side up) of channel pairs $\mathrm{C} 1$ and $\mathrm{C} 2$ is $32 \pm 2 \mathrm{~m}$ and $26 \pm 1 \mathrm{~m}$, respectively. Terraces along both sets of channels on the east side of the fault, but not on the west side, suggest that downcutting continued in these channels after offset, thereby providing an explanation for at least a portion of the apparent vertical separation. Some of the 
channels crossed by fault splays A, B, and C in the Qf1b surface exhibit right-lateral deflection but no offset.

\section{Stop 2: Queen Valley Thrust Fault}

Getting there: This stop is along Highway $6 \sim 4$ mi north of Benton. From the intersection of Highway 6 and Highway 120, drive north on Highway 6. After $\sim 3.3 \mathrm{mi}$, turn left (northwest) onto the dirt road. Drive northwest $\sim 0.4 \mathrm{mi}$ and park at the base of the hill on the east side of the road. Walk to the top of the hill $\left(37.8714^{\circ} \mathrm{N}, 118.4756^{\circ} \mathrm{W}\right)$.

At the southwestern end of Queen Valley, three faults, with different orientation and sense of offset, are exposed (Figs. 12 and 17). To the northwest is the well-exposed, NW-striking, linear Coyote Springs fault. This is a dextral fault based on the relatively topographically high exposure of a probable Qf2 surface, which we interpret as a pressure ridge at a left step along the trace of the fault. To the northeast, at the base of the northern end of the White Mountains, is the NE-striking Queen Valley normal fault. At this stop are a set of small, east-west-trending hills underlain by Pliocene(?) basalt lavas and Qf1 and Qf2 alluvial fan surfaces. In general, these hills are characterized by long, steep southern flanks and shorter, shallower northern flanks. We interpret these hills as anticlines in the hanging wall of south-vergent thrust faults. In support of this interpretation are playa deposits to the northeast, implying ponding up-fan from these hills, and the southeast projection into these hills of the Coyote Springs fault.

On the basis of the style and geometry of faults, we suggest that dextral slip along the White Mountains fault zone is partitioned here into two components-normal slip along the NE-striking Queen Valley fault and thrust slip along these WNWstriking thrust faults. The latter transfers slip to the dextral slip NW-striking Coyote Springs fault (Figs. 12 and 17).

\section{Stop 3: Queen Valley Normal Fault}

Getting there: This stop is at the mouth of Queen Canyon, $\sim 12$ mi northeast of Benton. From the intersection of Highway 6 and Highway 120 in Benton, drive north on Highway 6. After $\sim 9.5 \mathrm{mi}$, turn right (southeast) onto the dirt road. Drive southeast $\sim 2 \mathrm{mi}$ and park along the side of the road inside a small graben. Walk north onto the footwall of the southeast-dipping fault scarp $\left(37.9156^{\circ} \mathrm{N}, 118.3758^{\circ} \mathrm{W}\right)$.

At the mouth of Queen Canyon, six alluvial fan surfaces and several west- and east-facing normal fault scarps are exposed (Figs. 11 and 12). The oldest surface, an erosional remnant Qcf1, is preserved along a ridge extending along the south side of Queen Canyon. The extensive surface at the mouth of the canyon is a Qcf2 surface. Inset into this surface is Qcf3a, which in turn is inset by $\mathrm{Qcf} 3 \mathrm{~b}, \mathrm{Qcf} 3 \mathrm{c}$, and $\mathrm{Qcf3d}$. Cosmogenic radionuclide dating of quartz collected from surface boulders on Qcf2 yielded ${ }^{10} \mathrm{Be} \mathrm{CRN}$ model ages of $52.2 \pm 1.6 \mathrm{ka}$ and ca. $70 \mathrm{ka}$ for an interpreted remnant older debris flow.
The alluvial fan surfaces are cut by a zone of NE-striking, west- and east-dipping normal fault scarps and small grabens, with no evidence of a lateral component of slip. Topographic profiling across fault scarps yield vertical surface offsets ranging from 3.0 to $12.7 \mathrm{~m}$ of Qcf2 and $0.8-1.2 \mathrm{~m}$ of Qcf3a. Surfaces Qcf3b and Qcf3c have not been offset. The calculated net vertical offset of Qcf2 is $>16.6 \mathrm{~m}$, indicating a minimum vertical slip rate of $\sim 0.3 \mathrm{~mm} / \mathrm{yr}$ since ca. $52.2 \mathrm{ka}$. Assuming a $60^{\circ}$ fault dip yields $\sim 0.2 \mathrm{~mm} / \mathrm{yr}$ of horizontal extension.

\section{Stop 4: Intersection of Queen Valley and Coaldale Faults}

Getting there: This stop is along Highway $6, \sim 1.2 \mathrm{mi}$ west of Montgomery Pass. From the Queen Canyon turn-off, drive northeast on Highway 6 . After $\sim 7 \mathrm{mi}$, pull over along the north side of the road after the new highway bridge and park (be careful of traffic along the highway). Walk north of the parking area along old Highway $6\left(37.9700^{\circ} \mathrm{N}, 118.3389^{\circ} \mathrm{W}\right)$.

A left-lateral fault dominates a large portion of northern Queen Valley near Montgomery Pass. This fault represents the main strand of the western extent of the Coaldale fault. Fault striations are preserved within calcite and are found abundantly throughout a $4-5 \mathrm{~km}$ segment in the northwestern portions of the mapped area. The mean orientation of the fault plane and striations are $\sim 57^{\circ} / 89^{\circ}$ (strike/dip; $n=26$ ) and $56^{\circ} / 28^{\circ}$ (trend/plunge), respectively, indicating left-lateral motion with a small oblique component. The normal oblique component is responsible for the exposure of stratigraphically older units on the north side of the Coaldale fault (Fig. 21).

At this stop, the entire section of Tertiary volcanic rocks is offset by a complex array of faults where the Queen Valley and Coaldale faults appear to merge. Tertiary basalts are the youngest offset unit and constrain the timing of the fault to younger than $3 \mathrm{Ma}$ based on ${ }^{40} \mathrm{Ar} /{ }^{39} \mathrm{Ar}$ ages. Near Montgomery Pass, the rate of displacement along the Coaldale fault can be estimated from offset Pliocene basaltic-andesite. Basaltic-andesite scoria, found in a localized vent area directly south of the Coaldale fault, exhibits a minimum left-lateral offset of $\sim 1.2 \mathrm{~km}$ (Fig. 26). An ${ }^{40} \mathrm{Ar} /{ }^{39} \mathrm{Ar}$ age of $3.14 \pm 0.03$ Ma was obtained from a basaltic-andesite near the vent, indicating a minimum displacement rate of $\sim 0.4 \mathrm{~mm} /$ yr near Montgomery Pass. There is no evidence of active fault scarps in the late Quaternary alluvium found at Montgomery Pass. To the southwest of Montgomery Pass, the Coaldale fault appears to feather out into a number of smaller left-lateral faults, including a few exposed along the northern part of Queen Valley within Quaternary alluvial fan deposits (Fig. 12).

\section{Stop 5: Overview of Queen Valley and Middle Miocene Faulting}

Getting there: This stop is along the old, abandoned Carson and Colorado Railroad narrow gauge grade $\sim 19$ mi north of Benton. From Stop 4, continue east along Highway 6. After $\sim 0.5 \mathrm{mi}$, turn right (southwest) onto the dirt road with a constant 
grade. Drive along the railroad grade $\sim 1.6 \mathrm{mi}$ and park along a wide pull-out before the old railroad bridge. Walk $\sim 200 \mathrm{~m}$ along the railroad grade $\left(37.9602^{\circ} \mathrm{N}, 118.3305^{\circ} \mathrm{W}\right)$.

Along the eastern margin of the pull-apart structure, the main strand of the Queen Valley normal fault undergoes a transition from a NE-SW to a N-S strike. In this area, mainly Mesozoic granodiorite and Tertiary volcanic rocks are exposed in the footwall of the Queen Valley fault (Fig. 21). Fault displacement is transferred eastward into the footwall block along several ENE-striking normal faults. These top-down-to-the-NW relay faults offset Oligocene rhyolite and Miocene andesite and juxtapose them against Jurassic granodiorite. As we progress down the railroad grade, we walk down-section through the volcanic stratigraphy and cross over a number of these normal fault splays. Most of the faults in the Queen Valley area offset Miocene andesite; however, a number of the ENE-striking faults in this area are capped by this unit and predate the Queen Valley fault, suggesting that these structures may have reactivated preexisting Oligocene normal faults. All the relay faults are capped by late Pliocene rhyolitic ash-flow tuffs at high elevations near Sugarloaf Mountain, therefore constraining the lower limit of timing on these faults (Figs. 20 and 21).

\section{Stop 6: Central Segment of Coaldale Fault}

Getting there: This stop is along Highway 264 (to Dyer, Nevada), $\sim 1 \mathrm{mi}$ southeast of Highway 6. From the intersection of Highway 6 and Highway 264, drive south on Highway 264. After $\sim 1 \mathrm{mi}$, turn right (northwest) onto a dirt road or pull over along highway and park. Walk to the top of the hill $\left(37.9895^{\circ} \mathrm{N}\right.$, $\left.118.1925^{\circ} \mathrm{W}\right)$.

This stop presents an overview of both the geomorphic expression and offset geologic markers along the Coaldale fault. In the central portion of the study area, the eastern diatomite mine (Grefco Mines Inc.) is truncated on its southern boundary by the Coaldale fault (Figs. 22 and 24). A correlative outcrop of diatomite (5.3-3.6 Ma) is found on the south side of the Coaldale fault. The deposit is left-laterally offset $1.1 \pm 0.2 \mathrm{~km}$ (Fig. 22).

Stratigraphically above the eastern diatomite mine is a large deposit of basaltic andesite dated at 4.0 $\pm 1.3 \mathrm{Ma}$ (whole rock $\left.{ }^{40} \mathrm{Ar} /{ }^{39} \mathrm{Ar}\right)$. The outcrop capping the diatomite mine is truncated at its southern extent by the Coaldale fault. We correlate the capping basaltic andesite with an outcrop 350 m south of the Coaldale fault. The southern basaltic andesite was dated at $4.90 \pm 0.66 \mathrm{Ma}$ (whole rock ${ }^{40} \mathrm{Ar}{ }^{39} \mathrm{Ar}$ ). Projecting these capping outcrops to the Coaldale fault yields a calculated left-lateral offset of $1.1 \pm 0.3 \mathrm{~km}$.

\section{Stop 7: Eastern Segment of Coaldale Fault (Volcanic Hills)}

Getting there: This stop is along Highway 6, 5.5 mi east of the Mineral-Esmeralda county line. From the intersection of Highway 6 and Highway 264 (to Dyer, Nevada), drive east on Highway 6. After $\sim 4 \mathrm{mi}$, turn right (south) and park in large dirt pullout. Walk to an overview $200 \mathrm{~m}$ south of the pullout $\left(38.0081^{\circ} \mathrm{N}, 118.1313^{\circ} \mathrm{W}\right)$.
The northern flank of Volcanic Hills is characterized by thick deposits of late Pliocene basaltic andesite (3.14 $\pm 0.1 \mathrm{Ma})$ unconformably overlying tuffaceous sandstone and conglomerate of the Miocene Esmeralda Formation (Figs. 23 and 27). Within the Volcanic Hills area, the Coaldale fault system is characterized by a complicated array of EW- and ENE-striking fault scarps. Tectonic geomorphology such as deflected stream drainages, shutter ridges, sag ponds, and offset lobes of basalt indicate left-lateral slip is pervasive throughout the area (Figs. 23 and 25).

The Coaldale fault is located in an EW-trending linear valley on the western edge of Volcanic Hills. A linear fault scarp traverses basalt capping the Volcanic Hills from the valley's easternmost termination into a large NS-trending stream drainage. Directly east of the drainage, the Coaldale fault steps left from an EW-strike to an ENE-strike, creating a local releasing structure. The left-step in the fault system is characterized by an en echelon pattern of ENE-striking subparallel fault scarps merging with EW-striking fault scarps (Fig. 23). Blocks of basalt within the bend are vertically down-dropped and leftlaterally offset. Field mapping and 3-D imaging show that the EW-striking fault scarps within the bend are predominantly left-lateral while the connecting ENE-striking fault segments are predominately dip-slip. The faults merge directly east of the left-step and return to the original EW-strike. The EW-striking fault scarps emerging from the local releasing bend swing to an ENE orientation in central Volcanic Hills. The area does not display the geometry of the previously described transtensional structure and the bend is more gentle and on a larger scale. The ENE-striking fault scarps sinistrally offset stream drainages and lobes of basalt (Figs. 23 and 25).

Impressive examples of strike-slip tectonic geomorphologic features are pervasive throughout eastern Volcanic Hills (Fig. 25). Two distinct EW-trending linear valleys, interpreted as ancient fault strands, offset NS-trending stream drainages. A sag pond and bench pair, indicative of strike-slip motion, is present between the two linear valleys. On the northern flank of eastern Volcanic Hills are high angle, well-defined fault scarps and a shutter ridge, indicating the most recently active fault strand (Fig. 25). Because of the multitude of fault scarps and moderately offset stream drainages within Volcanic Hills, it is difficult to estimate a cumulative magnitude of left-lateral displacement. However, two stream drainages along separate fault strands within eastern Volcanic Hills are sinistrally offset $\sim 0.26 \mathrm{~km}$ and $\sim 0.23 \mathrm{~km}$. On the northern flank of Volcanic Hills, a distinctly separate fault strand sinistrally offsets a lobe of basalt $\sim 0.5 \mathrm{~km}$; this basalt was dated at $3.14 \pm 0.17\left({ }^{40} \mathrm{Ar} /{ }^{39} \mathrm{Ar}\right.$ whole rock $)$. The sum of measured left lateral offsets across Volcanic Hills is $\sim 1.1 \mathrm{~km}$ (Figs. 23 and 25).

\section{ACKNOWLEDGMENTS}

Research was supported by National Science Foundation grants EAR-0207365 and EAR-0125782 awarded to J. Lee and EAR0125879 (and a Research Experience for Undergraduate supplement) awarded to D. Stockli. 


\section{REFERENCES CITED}

Atwater, T., and Stock, J., 1998, Pacific-North America plate tectonics of the Neogene southwestern United States: An update, in Ernst, W.G., and Nelson, C.A., eds., Integrated Earth and Environmental Evolution of the Southwestern United States: Columbia, Maryland, Bellwether Publishing Ltd., p. 393-420.

Bennett, R.A., Wernicke, B.P., Niemi, N.A., Friedrich, A.M., and Davis, J.L., 2003, Contemporary strain rates in the northern Basin and Range province from GPS data: Tectonics, v. 22, p. 1008, doi: 10.1029/2001TC001355.

Bradley, D., 2005, The kinematic history of the Coaldale Fault, Walker Lane Belt, Nevada [M.S. thesis]: Lawrence, University of Kansas, 96 p.

Burchfiel, B.C., and Stewart, J.H., 1966, "Pull-apart" origin of the central segment of Death Valley, California: Geological Society of America Bulletin, v. 77, p. 439-442.

Burchfiel, B.C., Hodges, K.V., and Royden, L.H., 1987, Geology of Panamint Valley-Saline Valley pull-apart system, California: Palinspastic evidence for low-angle geometry of a Neogene range-bounding fault: Journal of Geophysical Research, v. 92, p. 10,422-10,426.

Crowder, D.F., and Ross, D.C., 1972, Permian(?) to Jurassic(?) metavolcanic and related rocks that mark a major structural break in the northern White Mountains, California-Nevada: U.S. Geological Survey Professional Paper P0800-B, p. B195-B203.

Crowder, D.F., Robinson, P.T., and Harris, D.L., 1972, Geologic map of the Benton Quadrangle, Mono County, California and Esmeralda and Mineral Counties, Nevada: U.S. Geological Survey Geologic Quadrangle Map GQ-1012, scale 1:62,500.

Dalrymple, G.B., and Hirooka, K., 1965, Variation of potassium, argon, and calculated age in a late Cenozoic basalt: Journal of Geophysical Research, v. 70, p. 5291-5296.

de Polo, C.M., 1989, Seismotectonics of the White Mountain fault system, eastern California and western Nevada [M.S. thesis]: Reno, University of Nevada, $354 \mathrm{p}$.

Dunne, G.C. and Walker, J.D., 2004, Structure and evolution of the East Sierran thrust system, east central California: Tectonics, v. 23, doi: 10.1029/2002TC001478.

Ernst, W.G., and Hall, C.A., 1987, Geology of the Mount Barcroft-Blanco Mountain area, eastern California: Geological Society of America Map and Chart Series MCH066, scale 1:250,000.

Gan, W., Svarc, J.L., Savage, J.C., and Prescott, W.H., 2000, Strain accumulation across the Eastern California Shear Zone at latitude $36^{\circ} 30^{\prime} \mathrm{N}$ : Journal of Geophysical Research, v. 105, p. 16,229-16,236, doi: 10.1029/2000JB900105.

Hardyman, R.F., and Oldow, J.S., 1991, Tertiary tectonic framework and Cenozoic history of the central Walker Lane, Nevada, in Raines, G.L., Lisle, R.E., Schafer, R.W., and Wilkinson, W.H., eds., Geology and Ore Deposits of the Great Basin Symposium Proceedings: Reno, Geological Society of Nevada, p. 279-301.

Krauskopf, K.B., 1968, A tale of ten plutons: Geological Society of America Bulletin, v. 79, p. 1-17.

Lee, J., Rubin, C.M., and Calvert, A., 2001, Quaternary faulting history along Deep Springs fault, California: Geological Society of America Bulletin, v. 113, p. 855-869, doi: 10.1130/0016-7606(2001)113<0855:QFHATD>2.0.CO;2.

McClusky, S.C., Bjornstad, S.C., Hager, B.H., King, R.W., Meade, B.J., Miller, M.M., Monastero, F.C., and Souter, B.J., 2001, Present day kinematics of the Eastern California Shear Zone from a geodetically constrained block model: Geophysical Research Letters, v. 28, p. 3369-3372, doi: 10.1029/2001GL013091.

McKee, E.H., Diggles, M.F., Donahoe, J.L., and Elliot, G.S., 1982, Geologic map of the White Mountains Wilderness and Roadless areas, California, and Nevada: U.S. Geological Survey Miscellaneous Field Studies Map MF-1361-A, scale 1:62,500.

McKee, E.H., and Conrad, J.E., 1996, A tale of 10 plutons, revisited; age of granitic rocks in the White Mountains, California and Nevada: Geological Society of America Bulletin, v. 108, p. 1515-1527, doi: 10.1130/00167606(1996)108<1515:ATOPRA >2.3.CO;2.

McQuarrie, N., and Wernicke, B.P., 2005, An animated tectonic reconstruction of southwestern North America since 36 Ma: Geosphere, v. 1, p. 147-172, doi: 10.1130/GES00016.1.
Miller, M.M., Johnson, D.J., Dixon, T.H., and Dokka, R.K., 2001, Refined kinematics of the eastern California shear zone from GPS observations, 1993-1994: Journal of Geophysical Research, v. 106, p. 2245-2263, doi: 10.1029/2000JB900328.

Oldow, J.S., 1992, Late Cenozoic displacement partitioning in the Northwest Great Basin, in Craig S.D., ed., Walker Lane Symposium: Structure, Tectonics \& Mineralization of the Walker Lane: Reno, Geological Society of Nevada, p. $17-52$

Oldow, J.S., Aiken, C.L.V., Hare, J.L., and Hardyman, R.F., 2001, Active displacement transfer and differential block motion within the central Walker Lane, western Great Basin: Geology, v. 29, p. 19-22, doi: 10.1130/00917613(2001)029<0019:ADTADB>2.0.CO;2.

Oswald, J.A., 1998, Quaternary geology of southern Saline Valley and neotectonic character of the Hunter Mountain fault zone [M.S. thesis]: Reno, University of Nevada, $69 \mathrm{p}$.

Owen, L.A., Gualtieri, L., Finkel, R.C., Caffee, M.W., Benn, D.I., and Sharma, M.C., 2001, Cosmogenic radionuclide dating of glacial landforms in the Lahul Himalaya, Northern India: Defining the timing of late Quaternary glaciation: Journal of Quaternary Science, v. 16, p. 555-563, doi: $10.1002 /$ jqs. 621

Owen, L.A., Finkel, R.C., Caffee, M.W., and Gualtieri, L., 2002, Timing of multiple glaciations during the late Quaternary in the Hunza Valley, Karakoram Mountains, Northern Pakistan: Defined by cosmogenic radionuclide dating of moraines: Geological Society of America Bulletin, v. 114, p. 593-604, doi: 10.1130/0016-7606(2002)114<0593:TOMLQG>2.0.CO;2.

Petronis, M.S., 2005, Cenozoic evolution of the Mina deflection, west-central Nevada [Ph.D. thesis]: Albuquerque, University of New Mexico, 286 p.

Robinson, P.T., McKee, E.H., and Moiola, R.J., 1968, Cenozoic volcanism and sedimentation, Silver Peak region, western Nevada and adjacent California: Geological Society of America, v. 79, p. 577-611.

Robinson, P.T., and Stewart, J.H., 1984, Uppermost Oligocene and lowermost Miocene ash-flow tuffs of western Nevada: U.S. Geological Survey Bulletin $1557,53 \mathrm{p}$

Schroeder, J., 2003, Pleistocene dextral fault slip along the White Mountains fault zone, California [M.S. thesis]: Ellensburg, Central Washington University, $62 \mathrm{p}$

Snow, J.K., and Wernicke, B.P., 2000, Cenozoic tectonism in the central Basin and Range; magnitude, rate, and distribution of upper crustal strain: American Journal of Science, v. 300, p. 659-719, doi: 10.2475/ajs.300.9.659.

Stevens, C.H., Stone, P., Dunne, G.C., Greene, D.C., Walker, J.D., and Swanson, B.J., 1997, Paleozoic and Mesozoic evolution of east-central California, in Ernst, W.G. and Skinner, B.J., eds., Clarence A. Hall, Jr. Symposium Proceedings: International Geology Review, v. 39, p. 788-829.

Stockli, D.F., Farley, K.A., and Dumitru, T.A., 2000, Calibration of the apatite $(\mathrm{U}-\mathrm{Th}) / \mathrm{He}$ thermochronometer on an exhumed fault block, White Mountains, California: Geology, v. 28, p. 983-986, doi: 10.1130/00917613(2000)028<0983:COTAUT>2.3.CO;2.

Stockli, D.F., Dumitru, T.A., McWilliams, M.O., and Farley, K.A., 2003, Cenozoic tectonic evolution of the White Mountains, California and Nevada: Geological Society of America Bulletin, v. 115, no. 7, p. 788-816, doi: 10.1130/0016-7606(2003)115<0788:CTEOTW $>2.0$. CO;2

Sylvester, A.G., 1988, Strike-slip faults: Geological Society of America Bulletin, v. 100, p. 1666-1703, doi: 10.1130/0016-7606(1988)100<1666: $\mathrm{SSF}>2.3 . \mathrm{CO} ; 2$.

Tincher, C.R., 2005, Cenozoic volcanism and tectonics in the Queen Valley area, Esmeralda County, western Nevada [M.S. thesis]: Lawrence, University of Kansas, 129 p.

Wernicke, B.P., and Snow, J.K., 1998, Cenozoic tectonism in the Central Basin and Range: Motion of the Sierran-Great Valley block, in Ernst, W.G., and Nelson, C.A., eds., Integrated Earth and Environmental Evolution of the southwestern United States: Columbia, Maryland, Bellwether Publishing Ltd., p. 111-118.

Wesnousky, S.G., 2005, Active faulting in the Walker Lane: Tectonics, v. 24 , p. TC3009, doi: 10.1029/2004TC001645.

Wilcox, R.E., Harding, T.P., and Seely, D.R., 1973, Basic wrench tectonics: American Association of Petroleum Geologists Bulletin, v. 57, p. 74-96.

Zehfuss, P.H., Bierman, P.R., Gillespie, A.R., Burke, R.A., and Caffee, M.C., 2001, Slip rates on the Fish Springs fault, Owens Valley, California, deduced from cosmogenic ${ }^{10} \mathrm{Be}$ and ${ }^{26} \mathrm{Al}$ and soil development on fan surfaces: Geological Society of America Bulletin, v. 113, p. 241-255, doi: 10.1130/0016-7606(2001)113<0241:SROTFS >2.0.CO;2. 